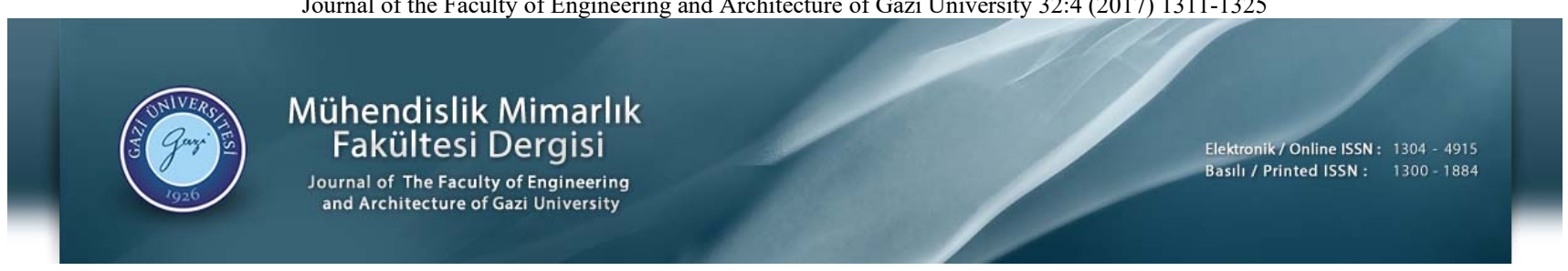

\title{
Stokastik sınır analizi kullanarak rüzgâr türbinleri için etkinlik değerlendirmesi
}

\author{
Harika Akalın $^{1}$ (D), Serap Ulusam Seçkiner1(D), Yunus Eroğlu ${ }^{1,2 *(D)}$ \\ ${ }^{1}$ Gaziantep Üniversitesi, Mühendislik Fakültesi, Endüstri Mühendisliği Bölümü, 27310 Gaziantep, Türkiye \\ ${ }^{2}$ İskenderun Teknik Üniversitesi, Mühendislik ve Doğa Bilimleri Fakültesi, Endüstri Mühendisliği Bölümü, 31200 İskenderun, Hatay, Türkiye
}

Ö N E Ç I K A N L A R

- $\quad$ Rüzgâr türbinlerinin etkinlik değerlendirmesi

- Stokastik sınır analizi ile verimlilik etkinliği modelleme

- Çeşitli parametrik girdilerin türbin etkinliği ölçümü üzerindeki etkileri

Makale Bilgileri

Geliş: 18.08.2016

Kabul: 22.11.2016

DOI:

10.17341/gazimmfd.369740

Anahtar Kelimeler:

Rüzgâr türbini, performans değerlendirme, stokastik sınır analizi

\section{ÖZET}

Bu çalışmada, Stokastik Sınır Analizi (SSA) tekniği, hâlihazırda işletmede olan bir rüzgâr çiftliğinde üretim etkinliğini ölçmek için kullanılmıştır. Mevcut literatürde çeşitli alanlarda yaygın olarak uygulanan bir etkinlik ölçüm tekniği olan SSA, rüzgâr türbinlerinin etkinlik ölçümlerinde daha önce kullanılmamıştır. SSA'nın stokastik yapısı, sınır sapmalarının hem işletmenin kontrolünde olmayan dış etkileri hem de teknik etkinsizliği içermesi onun anahtar özelliğidir. Önerilen yaklaşım, dört farklı senaryo altında her bir türbinin birbirlerine göre etkinliklerini ve rüzgâr çiftliğinin tamamının etkinliğini hesaplamak için kullanılmıştır. Bu senaryolar, çeşitli girdi parametrelerinin etkinlik üzerindeki etkisini ölçmek için oluşturulmuştur. Dolayısıyla, bu çalışmanın diğer bir amacı da farklı girdi senaryoları ile bir rüzgâr türbininin etkinliğini ölçmek için hangi faktörlerin ne kadar etkili olduğunu açıklamaktır. Ayrıca, bu dört senaryo, aylık ortalama veriler, on iki aylık veriler ve yirmi dört aylık veriler olmak üzere üç farklı zaman periyodunda çalışılmıştır. Çalışmanın sonucunda farklı girdi gruplarına göre farklı etkinlik skorları elde edilmiştir. Etkinlik kayıplarının istatiksel sapmadan mı yoksa etkinsizlikten mi kaynaklandığı SSA yönteminin avantajı gereği yorumlanabilmiştir.

\section{Efficiency evaluation for wind turbines using stochastic frontier analysis}

\section{H I G H L I G H T S}

- Efficiency evaluation of wind turbines

- Productive efficiency modelling by using stochastic frontier analysis

- Effects of various parametric inputs on measurement of turbine efficiency

Article Info

Received: 18.08 .2016

Accepted: 22.11.2016

DOI:

$10.17341 /$ gazimmfd. 369740

Keywords:

Wind turbine,

performance evaluation,

stochastic frontier analysis

\begin{abstract}
In this paper, Stochastic Frontier Analysis (SFA) technique is contributed to measure the productive efficiency of a working wind farm. In the current literature SFA, which is one of the commonly used efficiency analysis tool in many different areas, has not been studied previously to measure wind turbine efficiencies. Stochastic nature is the key advantage of SFA, whereby frontier deviations include both external effects that are not within the company's control and technical inefficiency. The proposed approach was used to calculate efficiency of each wind turbines to compare each other and to determine whole wind farm efficiency according to four different cases. These cases were introduced to determine the effects of different input parameters on the efficiency levels. Thereby, the other crucial interest of this study is to answer which factors are effective to measure the efficiency of a wind turbine by implementing four different input oriented cases. Also, these four cases studied under three different time periods; monthly averaged data, twelve monthly averaged data, and twenty four monthly data. Results showed that different input groups gave different efficiency results. Whether the efficiency loses originated from statistical noise or technical inefficiency could be concluded by the advantage of SFA.
\end{abstract}




\section{GIIRIŞ̧ (INTRODUCTION)}

Rüzgâr, dalga, güneş ve jeotermal enerji yenilenebilir enerji kaynakları arasında en çok bilinen enerji türleridir. $\mathrm{Bu}$ tarz enerjiler, doğanın yapısı sayesinde yenilenebilir oldukları için asla bitmeyecekmiş gibi tekrar tekrar kullanılabilirler. Sanayileşmenin günden güne artmasıyla ülkelerin enerji talepleri de hızla büyümektedir. Enerji güvenliği ve iklim değişikliği gibi politikacıların önem verdiği konular dikkate alındığında, ülkelerin enerji taleplerini karşılama stratejileri arasında yenilenebilir enerji kaynakları vazgeçilmez temiz ve yerel enerji kalemleri olarak düşünülmektedirler. Rüzgâr enerjisi, iklim değişikliği ve hava kirliliğini azaltmak için yapılan baskıları göz önünde tutarak, diğer enerji kaynakları arasında birçok ekonomik avantaja sahiptir [1]. Eski çağlardan bu yana, tarımda su pompalama ve yel değirmenleri, ulaşımda ise yelkenliler olmak üzere rüzgârı mekanik enerjiye çeviren sistemlerle beraber en yaygın yenilenebilir enerji kaynaklarından birisi olmuştur [2]. Günümüzde elektrik enerjisi elde etmek için modern rüzgâr türbinleri tasarlanmaktadır. Dünya genelinde çeşitli boyut ve kapasitelere sahip rüzgâr türbinleri kullanılmaktadır. Teknolojinin gelişmesi ve maliyetlerin düşmesiyle beraber enerji taleplerinin daha az sayıda türbin ile karşılanabilmesi için daha büyük ve daha yüksek kapasitelere sahip rüzgâr türbinleri geliştirilmektedir. Şekil 1'de modern rüzgâr türbinlerinin özellikle son on beş yılda hızla geliştiği ve günümüzde tek bir kanadı bile Airbus 380 yolcu uçağından daha uzun $(80 \mathrm{~m}$.) olan ticari türbinlerin üretildiği görülebilir [3].

Çeşitli kurumların yayımladıkları raporlara göre, güncel rüzgâr enerji sektörü aşağıdaki gibi özetlenebilir [4, 5];

- Rüzgâr enerjisi yüz on üç ülkede kullanılmaktadır,

- Küresel yeni eklenen rüzgâr enerji kapasiteleri Şekil 2'de görülmektedir,

- 2015 yılında yenilenebilir enerjiye yapılan yatırım 296,6 milyar Euro olmuştur

- Dünya genelinde 2015 y1lı sonuna kadar toplam rüzgâr enerjisi kurulu güç kapasitesi 432,9 GW olmuştur,

- 2015 yılında 63 GW yeni kapasite eklenmiştir,

- Çin tek seferde 30,8 GW yeni kapasite ekleyerek bir rekor kırmıştır,

- Türkiye yaklaşık 5GW toplam kurulu kapasitesiyle, Avrupa Birliği dışındaki en büyük pazara sahip Avrupa ülkesi olmuştur.

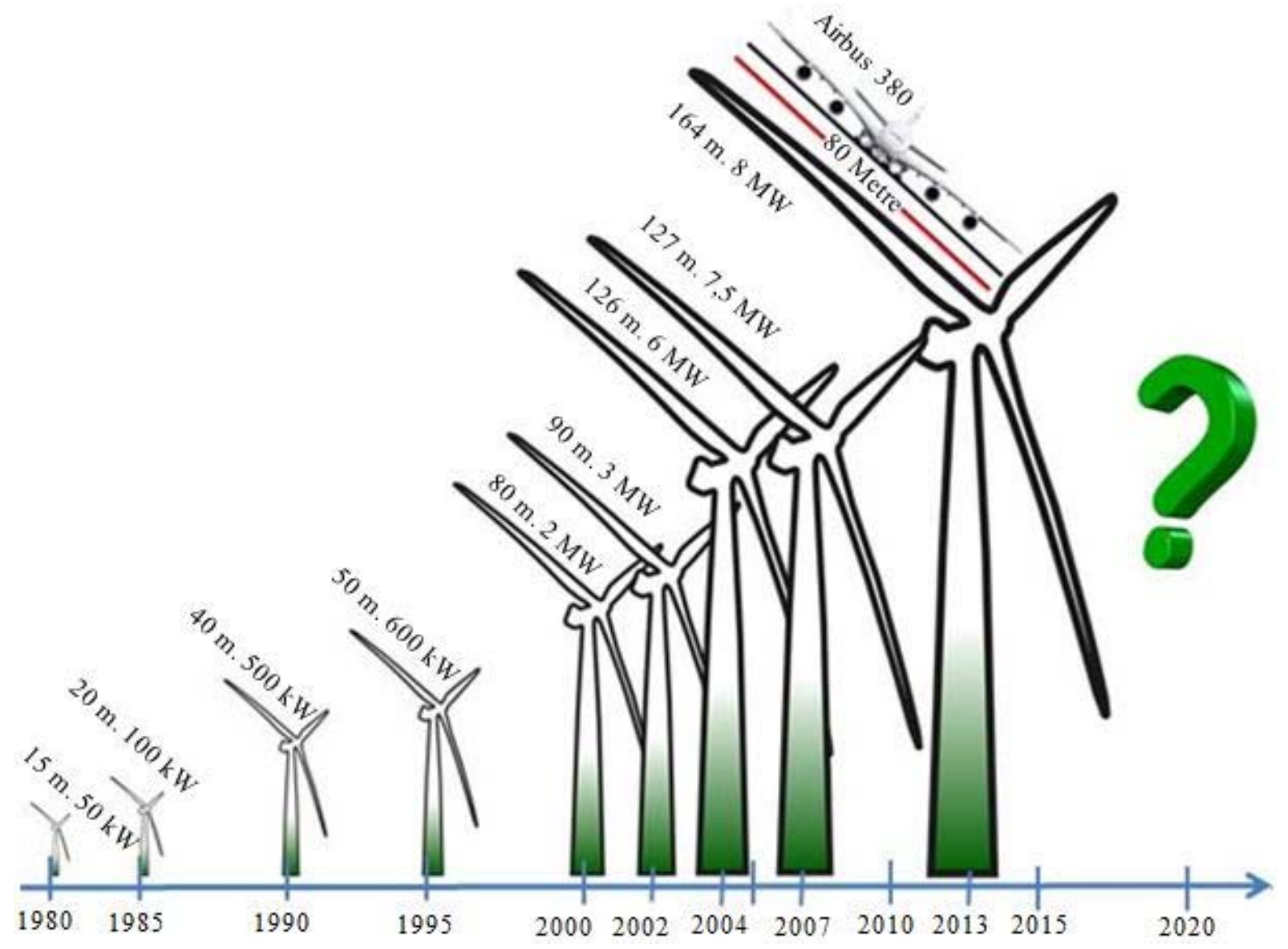

Şekil 1. Modern rüzgâr türbinlerinin yıllara göre gelişimi (Rotor çapları metre $(\mathrm{m})$, kapasiteleri kilovat (kW) ve megavat (MW) olarak) [3] (The evolution of modern wind turbines according to years (Rotor diameters in meters $(\mathrm{m})$ and capacities in kilo-watts $(\mathrm{kW})$ and mega-watts (MW)) 


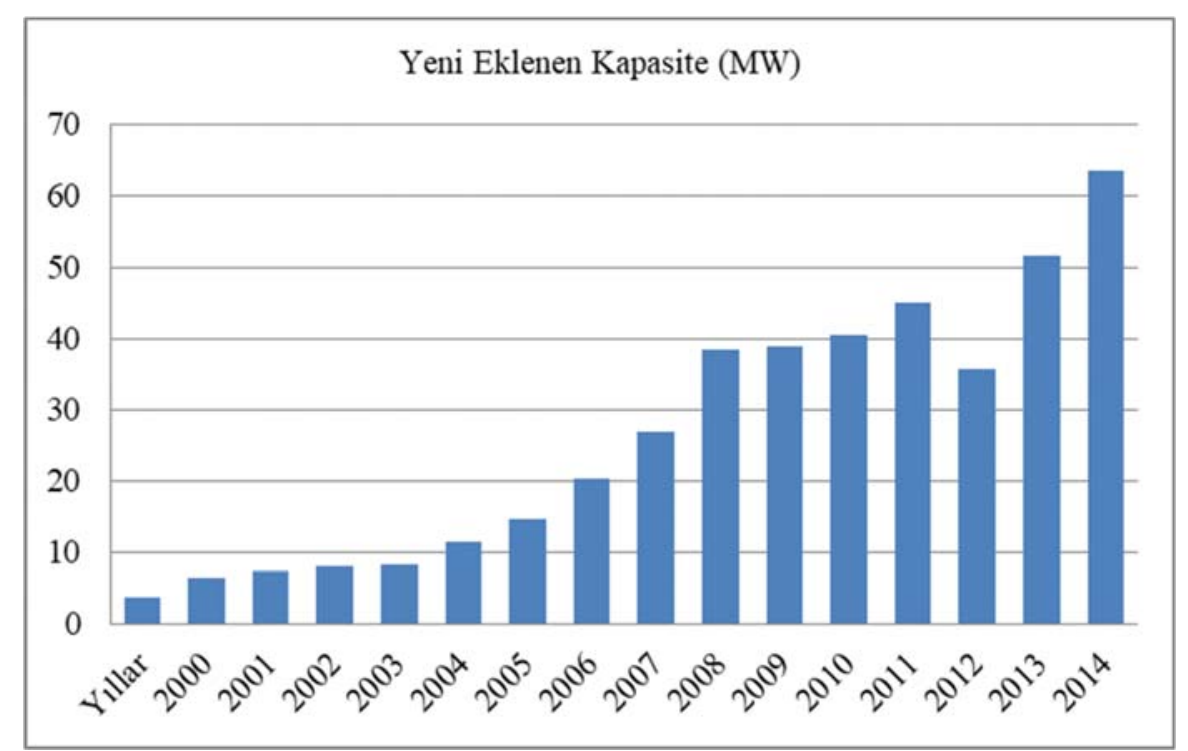

Şekil 2. 2000 - 2015 yılları arası küresel yeni eklenen rüzgâr enerji kapasiteleri (GWEC, 2016 [4]) (Global new installed wind energy capacities between the years 2000 and 2015)

Rüzgâr enerji sektöründeki yatırımlar küresel çerçevede hızla artmaktadır ve artan yatırımların risk analizleri incelenmesi gereken önemli bir konudur [6]. Bu durum göz önünde bulundurulduğunda yatırımlarda uygun teknolojilerin seçilmesi de önem arz etmektedir [7]. Ayrıca, yatırımcılar küresel ve yerel pazardaki yerlerini koruyabilmek için mevcut rüzgâr çiftliklerinde maliyetleri düşürecek kontrol ve izleme araçları geliştirmek için büyük çaba göstermektedirler [8]. Eroğlu ve Seçkiner'in [9] hazırladıkları bir çalışmaya göre, rüzgâr enerjisi ile ilgili yapılan 7000'den fazla makale incelenmiş ve özellikle son dönemlerde maksimum güç üretimine, en etkin parametrelerle beraber yönetimsel amaçlarla ve bu doğrultuda dinamik ve ak1llı kontrol yöntemlerine odaklanıldığı belirtilmiştir. Özetle, mevcut literatüre göre akademik çalışmalar "Bir rüzgâr santrali hangi etkin parametrelerde en yüksek performansta çalışır?" sorusuna yanıt arar niteliktedir [3]. Rüzgâr santrallerinde türbinlerin etkinlik analizleri de aynı doğrultuda kontrol ve izleme amaçlı performans göstergeleri olarak kullanılabilirler. İşletme maliyetlerini düşürmenin yollarından birisi eldeki kaynakları en etkin şekilde kullanarak en çok gücü üretmektir. Bu sebeple etkinlik analizleri rüzgâr santralleri için büyük önem arz etmektedir. Rüzgâr türbinlerinde ve santrallerinde genellikle etkinlik analizi çalışmalarına doğrudan rastlanılmamakla beraber bir kaç çalışma mevcuttur. Performans analizi başlığı altında türbinlerin veya çiftliklerin verimlilikleri incelenmiş fakat bunlar da genellikle mekanik tasarımları içeren deneysel çalışmalarla sınırlanmışlardır. Denholm vd. [10] rüzgâr enerjisinin temel yükü oluşturduğu sistemlerde enerji etkinliğini modellemiş ve incelemişlerdir. Mirecki vd. [11] simülasyon kullanarak rüzgâr türbininin güç faktörünü modellemişler ve enerji etkinliğini analiz etmişlerdir. Zhang ve Tolbert [12] rüzgâr türbinlerinin güç çevrim ünitelerinde silikon karbid (SiC) kullanarak etkinliği arttırdığını vurgulamışlardır. De Prada Gil vd. [13] deniz üzeri rüzgâr santrallerinin güç üretim etkinliklerini jeneratörleri kontrol eden tekli-büyük-güççeviricisi kullanarak analiz etmişlerdir. Literatürde, etkinlik analizi başlığını içeren çalışmaların yanında performans analizi başlıklı birçok çalışmaya rastlamak mümkündür. Performans analizi çalışmaları ise kendi aralarında türbin tasarımı, kontrol parametrelerinin tasarımı, güç eğrisinin modellenmesi, teknik performans ve izleme yöntemleri ile ilgili araştırmalar olarak gruplanabilirler. Tasarım odaklı performans arttırıcı çalışmalara örnek verecek olursak; Najar [14] kanat aerodinamik performansını tahmin etmek için rüzgâr türbini kanat tasarımı optimizasyonu yapmıştır. Jiang vd. [15] sonsuz kaldırma-sürükleme oranına sahip yeterli sayıda kanadı olan ideal rüzgâr türbininin performansını incelemişlerdir. Chehouri vd. [16] rüzgâr türbinlerinin performans optimizasyonu üzerine uygulanan teknikleri araştırmışlardır. $\mathrm{Bu}$ araştırmada, son 30 yıl boyunca amaç fonksiyonunun ilk zamanlardaki güç katsayısının maksimizasyonundan yıllık üretilen gücün maksimizasyonuna dönüştüğü yorumlanmıştır. $\mathrm{Bu}$ arada, rotor tasarımı araştırmalarında ise El-Baz vd. [17] yeni bir tasarım olarak üçgen bir modele göre yapılan üç-rotorlu Savonius tipi türbin geliştirdiklerini yayımlamışlardır. Bu yeni tasarımın tek rotora sahip tasarımlardan daha yüksek güç katsayılarına sahip oldukları sunulmuştur. Kontrol tasarımı da performans analizi konusunu teknik açıdan ele alan çalışmalar arasında sayılabilir. Astolfi vd. [18] SCADA (Supervisory Control And Data Acquisition - Gözetleyici Kontrol ve Veri Toplama Sistemi) verileri üzerinde veri madenciliği teknikleri kullanarak rüzgâr santrallerinde performans analizleri yapmıştır. Mengi ve Altaş [19] çalışmalarında Bulanık Mantık yaklaşımı ile rüzgar hızı, basınç, nem vb. bilgileri kullanmadan sadece sisteme ait akım ve gerilim bilgileri ile tepe güç noktasını izleyen bir algoritma sunmuşladır. Bayrak vd. [20] ise bakım ve arıza maliyetlerinin azaltılması amacıyla elektriksel ölçümlere dayanan ve mekanik dengesizlik durumlarını algılayan yeni bir durum izleme algoritması geliştirmişlerdir. Çeşitli hibrit 
tasarımların performans analizlerine de literatürde rastlamak mümkündür. Devrim ve Bilir [21] PV güneş, rüzgar ve proton yakıt hücresinden oluşan ve $150 \mathrm{~m}^{2}$ lik bir evin ihtiyacını karşılayabilecek hibrit bir sistem tasarlamışlar ve bu sistemin gerekli elektrik ihtiyacını karşılamadaki performansını incelemişlerdir. Güç eğrisi modelleme rüzgâr enerjisi alanında performans ölçüm aracı olarak en yaygın kullanılan yöntemler arasında sayılabilir. Uluyol vd. [22] muhtemel üretilebilecek güç ile gerçekleşen arasındaki fark1 hesaplayabilmek için güç eğrisini ve mevcut üretim durumunu kullanan bir metot geliştirmişlerdir. Literatürde bulunan güç eğrisi modelleri Carrillo vd. [23] ve Lydia vd. [24] tarafindan derlenmiştir. Milan vd. [25] rüzgâr çiftliğini dinamik bir sistem olarak tasarlamıș ve böylece performans ölçümüne stokastik açıdan bakılabileceğini göstermiştir. Son olarak, Herp vd. [26] rüzgâr çiftliklerinin performansını izleyebilmek için veri işlemine dayanan, Bayes sınıflandırması ve çok değişkenli çözümleme yaklaşımlarıyla, en güncel güç eğrisi modelini sunmuştur. Ayrıca, Kusiak ve Verma [27, 28] güç eğrisi, rotor eğrisi ve kanat açısı eğrisini kullanarak rüzgâr türbinlerinin izlenmesini performans ölçüm metodolojisi olarak anlatmışlardır.

Rüzgârın karakteristik özellikleri ve diğer atmosferik veriler de literatürde sıklıkla rüzgâr enerji sistemlerinin performans değerlendirmeleri için kullanılmıștır. Rüzgâr hızının profili [29, 30]; rüzgâr hızı, yönü, türbülans ve atmosferik durağanlık ile performans arasındaki ilişki [31]; rüzgâr profili ile ilgili çalışmalara örnek verilebilir. Bunların dışında, Pieralli vd. [32] belli bir rüzgâr hızı ve hava yoğunluğunda üretilebilecek en yüksek elektrik enerjisini temsil eden etkin üretim sınırı hesaplamışlardır. Güç üretim maliyetinin işletme ve bakım maliyetleri dikkate alındığında etkinlik göstergesi olduğunu konu edinen çalışmalar da mevcuttur [33, 34]. Bu çalışmalarda üretim etkinliğini arttırmanın üretim maliyetini doğrudan düşürmeyeceği, bunun sebebinin de bakım maliyetinin artması olduğu vurgulanmaktadır. Genel olarak rüzgâr çiftliklerinde performansı etkileyen rüzgâr hızı, elektrik piyasası, talepler ve fiyatlar gibi bir çok faktörün incelenebildiği görülmüștür [35]. Ayrıca, üretilen gücü en yüksek yapabilecek türbinlerin yerleşim planları çalışmaları da literatürde oldukça yaygındır. Bu alanda Eroğlu ve Seçkiner [36, 37] karınca koloni optimizasyonu ve parçacık filtreleme yaklaşımlarıyla sınırlı bir alanda rüzgar türbinlerinin yerleşimini belirlerken Lo vd. [38] Çin'de yer alan rüzgar çiftliklerinin performanslarını yerleşimlerine göre incelemiştir. Iglesias vd. [39] SSA ve VZA yöntemlerini rüzgâr çiftliklerinin etkinlik analizleri için kullanmışlardır. Sundukları çalışmada farklı rüzgâr santralinin etkinliklerini ișçi, ana para, yakıt gibi girdilerle kıyaslamışlar ve türbin bazında analiz yapmamışlardır. Eroğlu ve Seçkiner [3] VZA ile rüzgâr türbinlerinin etkinlik analizi yapılabileceğini göstermişlerdir. Çalışmalarında girdi olarak sadece rüzgâr hızı, jeneratör hızı ve rotor hızı kullanılmış ve üretilen gücün etkinliği incelenmiştir. $\mathrm{Bu}$ referanslar dikkate alındığında herhangi bir rüzgar santralinde türbinlerin etkinlik analizi SSA ile yapılabileceği düşünülmüştür. Dolayısıyla, önerilen yaklaşımda bir rüzgâr santralindeki türbinlerin etkinlikleri SSA yöntemiyle dört farklı girdi senaryoları kullanılarak kıyaslanmıştır. Dördüncü senaryo literatürdeki Eroğlu ve Seçkiner'in [3] çalışmalarıyla kıyaslama yapabilmek için aynı girdi ve çıktılardan oluşmaktadır. Elde edilen etkinlik skorları girdi türlerine göre yorumlanmıştır. Bu yorumların en büyük avantajı etkinsizliğin girdi türüne göre gözlemlenmesiyle herhangi bir arıza durumunun hangi girdi parametresiyle ilgili olduğu hakkında fikir vermesidir. SSA ilk olarak Aigner vd. [40] ve Meeusen ve Broeck [41] tarafından 1977 yılında birbirlerinden bağımsız olarak literatüre sunulmuştur. Maliyet, üretim, satış ve kâr gibi birçok farklı modellerle kullanılabilir. Mevcut literatürde SSA ile yapılmış enerji sektöründen çalışmalar da mevcuttur. Bir vaka çalışması olarak, OECD (Organization for Economic Cooperation and Development - Ekonomik İşbirliği ve Kalkınma Örgütü) ülkeleri için ekonomi ölçekli üretim etkinliği analizi Zhou vd. [42] tarafindan sunulmuştur. Bir başka çalışmada, $\mathrm{Hu}$ ve Honma [43] SSA ile OECD ülkeleri için toplam faktör enerji skorlarını tahmin etmiştir. Kurumsal binalarda soğutma sisteminin enerji etkinliği Yu vd. [44] analiz edilmiştir. Farklı bir bakış açısı olarak Çin'deki kimya sektörünün enerji etkinlik analizi Lina and Long [45] tarafından yine SSA yöntemiyle çalışılmıştır. Özetle, bu çalışmanın amacı bir rüzgâr çiftliğinde türbinlerin ve çiftliğin enerji üretim etkinliğini hesaplayacak bir alternatif yaklaşım sunmaktır. $\mathrm{Bu}$ doğrultuda, literatürde birçok farklı alanda uygulanan SSA, rüzgâr türbinleri etkinlik analizinde ilk defa kullanılmıştır. Bir sonraki bölümde uygulanan yöntem ve matematiksel modeller detaylarıyla verilmiştir. Problem tanımı, senaryoların detayları, metodolojinin uygulanması ve bulgular üçüncü bölümde verilmiştir. Son olarak dördüncü bölümde sonuçlar ve yorumlar verilmiştir.

\section{TEORIK METOT (TEORICAL METHOD)}

Etkinlik analizi yöntemleri arasında sıklıkla kullanılan SSA'nın orijinal üretim fonksiyonları Battese ve Coelli [46] tarafindan 1995 yılında FRONTIER ismi ile ücretsiz bir bilgisayar programı haline getirilmiştir ve bu çalışmada yapılan analizler bu program kullanılarak ortaya koyulmuştur. Geliştirmiş oldukları programda üretim etkinliklerini, maliyet ve kâr sınırlarını ve ekonomik sınırları hesaplayabilmek için Aigner vd.'nin [40] Ekonometri Uydurma Tekniği modelini kullanmışlardır. Kullanılan model yatay kesitli veriler için özelleştirilmiş, Eş. 1'de gösterildiği üzere, rastlantısal simetrik istatiksel hata ve tek yönlü etkinsizlikten kaynaklanan sistematik bir sapmadan oluşan iki farklı bileşeni olan bir üretim fonksiyonu tanımlar, burada $y$ çıktıyı, $X$ girdi vektörünü, $\beta$ bilinmeyenlerden oluşan katsayı vektörünü, $v$ çift yönlü istatiksel hatayı ve $u$ negatif olmayan normal veya herhangi bir dağılıma uyan tek yönlü rastlantısal sistematik sapmayı göstermektedir.

$y=f(X, \beta)-u+v$

Ayrıca $u$ ve $v$ birbirlerinden ve diğer değişkenlerden bağımsızdırlar. Bu arada, FRONTIER programında, sınırları 
ve etkinsizlikleri tahmin etmek için maksimum olasılık teknikleri kullanılmaktadır. SSA orijinalinde yatay eksenli verilerin etkinlik analizini yapmak için geliştirilmiş olsa da Battese ve Coelli [46] Eş. 2'de görüldüğü üzere zaman dilimlerinden oluşan panel veriler için SSA modelini geliştirmişlerdir. Eş. 2'de yit çıktıyı (bu çalışmada üretilen ortalama gücü), $X_{i t}$ girdileri, $\beta$ bilinmeyen üretim parametrelerini/katsayılarını, $\varepsilon_{i t}$ ise istatiksel sapma $\left(V_{i t}\right)$ ve teknik etkinsizlikten oluşan $\left(-U_{i t}\right)$ hata bileşenini göstermektedir. Alt indis $i$ her bir rüzgâr türbinini $(i=1,2, \ldots$, 16) ve $t$ ise aylık olarak ortalaması alınmış iki yıl için ondakika-aralıklı verileri sembolize etmektedir $(t=1,2, \ldots \ldots$, 24).

$\mathrm{y}_{\mathrm{it}}=\mathrm{f}\left(\mathrm{X}_{\mathrm{it}}, \beta\right)+\varepsilon_{\mathrm{it}}=\mathrm{f}\left(\mathrm{X}_{\mathrm{it}}, \beta\right)+\mathrm{V}_{\mathrm{it}}-\mathrm{U}_{\mathrm{it}}$

Çalışmada FRONTIER programının son versiyonu olan FRONTIER 4.1 kullanılmıştır. Bu program Eş. 2'deki hesaplamaları logaritmik fonksiyona dönüştürerek yapmakta olup güncellenmiş model Eş. 3 'te gösterildiği gibidir:

$\ln \left(y_{i t}\right)=\ln \left(X_{i t}, \beta\right)+\left(V_{i t}-U_{i t}\right)$

FRONTIER 4.1 programının etkinlik hesaplaması ise Eş. 4'te verilmiştir, burada $Y_{i}^{*}=i$ türbininin logaritması alınmış güç üretimini, $X_{i}=i$ türbininin logaritması alınmış girdilerini, $U_{i}=i$ türbininin etkinsizliğini ve Etkinlik $k_{i}$ ise $i$ türbininin etkinliğini belirtmektedir.

Etkinlik $_{\mathrm{i}}=\mathrm{E}\left(\mathrm{Y}_{\mathrm{i}}^{*} \mid \mathrm{U}_{\mathrm{i}}, \mathrm{X}_{\mathrm{i}}\right) / \mathrm{E}\left(\mathrm{Y}_{\mathrm{i}}^{*} \mid \mathrm{U}_{\mathrm{i}}=0, \mathrm{X}_{\mathrm{i}}\right)$

Analiz sonuçlarına göre etkinsizliğin istatiksel sapmadan mı yoksa teknik etkinsizlikten mi kaynaklandığının anlaşılabilmesi için $\gamma$ (gama) parametresinin incelenmesi gerekmektedir. Eş. 5 ile hesaplanan standart sapmanın karesi $\delta^{2}$ istatiksel sapmaların ve teknik etkinsizlikten oluşan hataların karesinin toplamından oluşmaktadır. Eş. 6' da ise gama'nın eşitliği verilmektedir.

$\delta^{2}=\delta \mathrm{v}_{2}+\delta \mathrm{u}^{2}$

$\gamma=\delta u^{2} / \delta^{2}, \gamma \in[0,1]$

Eş. 6'dan anlaşılacağı üzere, $\gamma$ 1'e eşitse etkinsizliğin teknik etkinsizlikten kaynaklandığ 1 ve tam tersi olarak $\gamma 0$ 'a eşitse etkinsizliğin istatiksel sapmadan kaynaklandığı yorumları yapılabilir [47]. SSA yönteminin VZA'dan ayırt edici avantajları arasinda gama parametresi sayesinde etkinsizliğin sebebini yorumlayabilmek gösterilebilir. $\mathrm{Bu}$ çalışmada kullanılan matematiksel metotların, parametrelerin ve çıktıların detaylarını programın rehberi olan kaynak [48]'den ulaşılabilir.

Literatürde çeşitli etkinlik ve performans analizi yöntemleri olmasına karşın SSA yöntemi ile daha önce rüzgâr türbinlerinin etkinlikleri incelenmemiştir. Parametrik olan SSA stokastik yapısından dolayı kontrol edilemeyen istatiksel sapmaları ve teknik etkinsizliği ayırt edici bir avantaja sahiptir [49]. $\mathrm{Bu}$ sebepler göz önünde bulundurularak, bu çalışmada SSA'nın kullanılması rüzgâr türbinlerinin etkinlik ölçümlerine yeni bir metot olarak sunulmuştur.

\subsection{Problem Tanımı (Problem Statement)}

Rüzgâr türbinlerinin etkinliklerinin hesaplanması ve zamanla nasıl değiştiği bu çalışmanın temel amaçlarındandır. $\mathrm{Bu}$ amaç doğrultusunda Türkiye'de faaliyet gösteren bir rüzgâr çiftliğinden iki yıllık işletme verileri toplanmıştır. Bu çiftlikte toplamda on altı tane $3 \mathrm{MW}$ kapasiteli $90 \mathrm{~m}$. kanat çaplı ve $80 \mathrm{~m}$. göbek yüksekliğine sahip türbinler bulunmaktadır.

Güç eğrisi (Şekil 3) rüzgâr enerjisinde performans göstergesi olarak yaygın şekilde kullanılmaktadır. Bu eğri rüzgâr hızı ile üretilen güç arasındaki ilişkiyi göstermektedir. Şekil 3'teki yeșil/açık renkli noktalar gerçekleșen güç üretimini siyah noktalar ise ideal güç eğrisini göstermektedir. İdeal eğri dışında kalan tüm noktalar üretimdeki sapmalardır. Her ne kadar bir performans göstergesi olarak ilk önce güç eğrisi incelense de tek başına etkinsizliklerin neden ve ne zaman gerçekleştiği konusunda herhangi bir ipucu vermemektedir. Bu çalışmada etkinlik hesaplamalarında kullanılması için her türbinin SCADA sisteminden elde edilen 10-dakikalık ortalamalarda jeneratör hızı, rotor hızı, rüzgâr hızı, rüzgâr yönü, jeneratör rulman sicaklığı, hidrolik yağ sıcaklığı, motor yeri sıcaklığ1, şebeke bağlantı yeri sıcaklığı, kontrol merkezi sıcaklığı, spiner (kanatların bağlantı yeri) sıcaklığı ve üretilen güç verileri kullanılmıştır. Girdi türlerine göre dört farklı senaryo oluşturulmuş ve tüm senaryolarda üretim etkinliği incelenmek istendiği için ortalama üretilen güç çıktı olarak alınmıştır. İlk senaryoda mekanik hızlar girdi, üretilen güç ise çıktı olarak kullanılmıştır. $\mathrm{Bu}$ senaryonun oluşturulmasındaki temel sebep Eş. 7'de gösterildiği üzere jeneratör hızı ve rotor hızının üretim etkinliği üzerindeki etkisini analiz etmektir.

$\ln (\ddot{\text { UrretilenGüçi }})=\beta_{0}+\beta_{1} \ln ($ JeneratörHızı $)+$ $\beta_{2} \ln ($ RotorH1z1 $)+\mathrm{V}_{\mathrm{i}}-\mathrm{U}_{\mathrm{i}}$

İkinci senaryoda jeneratör rulman sıcaklığ 1 , hidrolik yă̆ sicaklığı, motor yeri sicaklığ 1 , şebeke bağlantı yeri sicaklığ 1 , kontrol merkezi sicaklığı, spiner (kanatların bağlantı yeri) sıcaklığı gibi sıcaklıklar girdi olarak alınmıştır. $\mathrm{Bu}$ senaryonun SSA modeli Eş. 8'de verilmiştir.

$\ln \left(\ddot{U ̈ r e t i l e n G u ̈ c ̧}_{\mathrm{i}}\right)=\beta_{0}+\beta_{1} \ln ($ JeneratörRulmanS1caklığ 1$)+$ $\beta_{2} \ln ($ HidrolikYağSicaklığı $)+\beta_{3} \ln ($ MotorYeriSıcaklığ $)+$ $\beta_{4} \ln ($ ŞebekeBağlantıYeriSıcaklığı 1$)+$

$\beta_{5} \ln ($ KontrolMerkeziSicaklığ 1$)+$

$\beta_{6} \ln ($ SpinnerSicaklığı $)+V_{i}-U_{i}$

Rüzgâr verileri ile ilgili girdilerden oluşan üçüncü senaryoda üretilen gücü etkileyen en temel parametre olan rüzgâr hızı verileri ve rüzgâr yönü verisi kullanılmıştır. Yapılan bu etkinlik analizi rüzgâr enerjisi eşitliğindeki güç formülüyle kıyaslanmamalıdır. Bilinen rüzgâr hızında bilinen teknik özelliklere sahip bir rüzgâr türbininin üreteceği teorik güç 


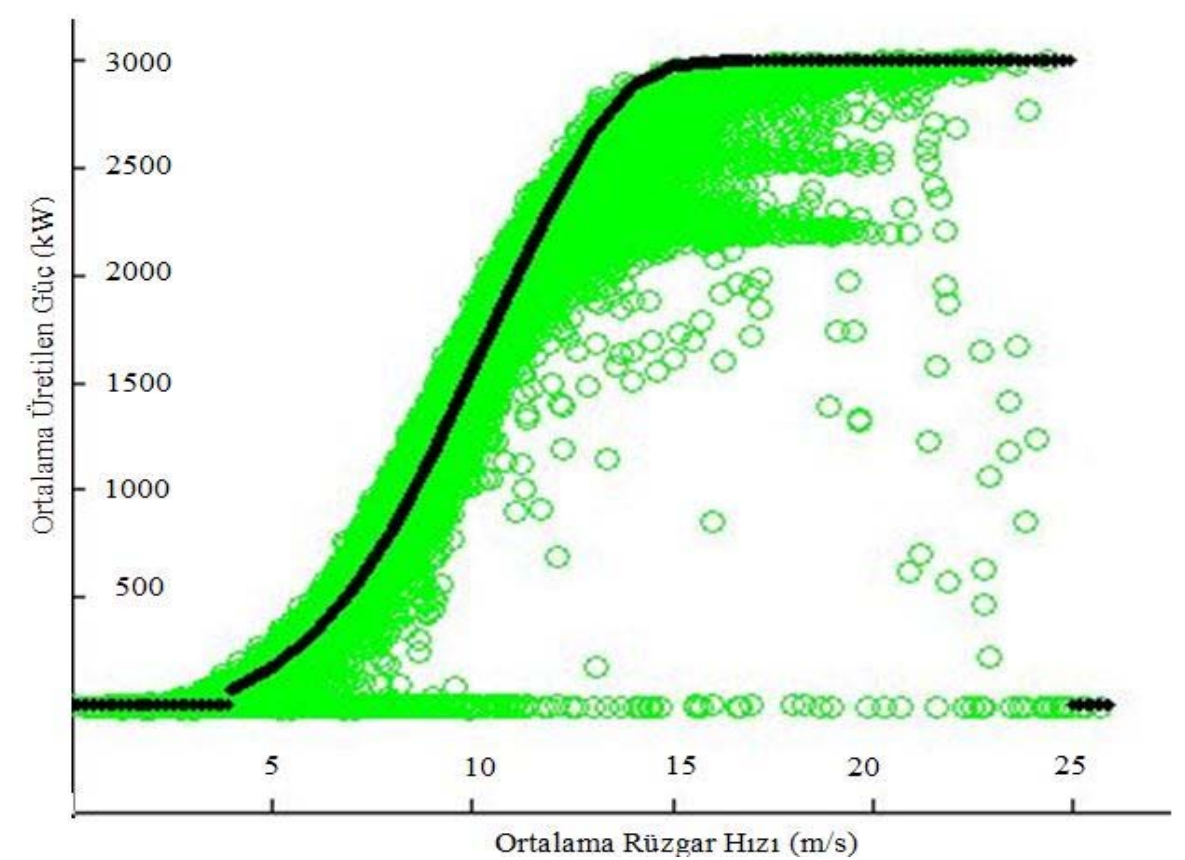

Şekil 3. Bir rüzgâr türbininin iki yıllık dönem için güç eğrisi (yeşil - açık renk noktalar) ile ideal eğri (siyah noktalar) (Power curve of a wind turbine for two year period (green - light dots) versus Ideal Power Curve (black dots))

elbette hesaplanabilmektedir. Fakat bu çalışmada verilen modellerin üretilen gücün hesaplanmasıyla bir ilgisi olmayıp; belirli girdilerle, benzer şartlarda, birbirlerinden farklı üretim profillerine sahip özdeş türbinlerin etkinliklerini hesap edebilmek için geliştirilmişlerdir. Dolayısıyla bu senaryonun modeli olan Eş. 9 ve daha önceki ve sonraki diğer senaryodaki eşitliklerin teorik güç formülleriyle kıyaslanmaması ve karıştırılmaması gerekmektedir.

$\ln \left(\ddot{U ̈ r e t i l e n G u ̈ c ̧}_{\mathrm{i}}\right)=\beta_{0}+\beta_{1} \ln ($ OrtalamaRüzgarHızı $)+$ $\beta_{2} \ln ($ MaksimumRüzgarHızı) +

$\beta_{3} \ln ($ MinimumRüzgarHızı) +

$\beta_{4} \ln ($ RüzgarYönü $)+V_{i}-U_{i}$

Son senaryoda ise üretilen güç ile doğrudan ilişkili olan ve Eroğlu ve Seçkiner'in [3] çalışmalarında kullanılan girdiler olan jeneratör hızı rotor hızı ve rüzgâr hızı karma veri girdileri olarak kullanılmıştır. Bu çalışma ile literatürdeki mevcut çalışmayı kıyaslayabilmek için aynı girdi verileri bu senaryoda kullanılmıştır. Rüzgâr hızı, jeneratör hızı ve rotor hızı mevcut literatürde sıklıkla güç üretiminin verimliliğini incelemek için mercek altında tutulan parametrelerdir. Bu parametreler SSA yöntemi ile Eş. 10'daki gibi modellenmiştir.

$\ln \left(\right.$ ÜretilenGüçi $\left._{i}\right)=\beta_{0}+\beta_{1} \ln ($ JeneratörHız1 $)+$

$\beta_{2} \ln ($ RotorHızı $)+\beta_{3} \ln ($ RüzgarHızı $)+V_{i}-U_{i}$

\section{SONUÇLAR VE TARTIŞMALAR (RESULTS AND DISCUSSIONS)}

Bu bölümde dört farklı senaryo üzerinde SSA yöntemiyle rüzgâr türbinleri için etkinlik analizi sonuçları verilmiş ve yorumlanmıştır. Oluşturulan bütün senaryolar farklı girdi gruplarının etkinlik üzerindeki etkisinin anlaşılması için tasarlanmıştır. Ayrıca daha farklı girdi grupları oluşturularak daha farklı sonuçlar elde edilebileceği gösterilmiştir. 12 aylık ve 24 aylık etkinlik analizleri panel veri yaklaşımıyla sunulmuştur. Aşağıdaki bölümlerde her senaryo için aylık etkinlik analizleri verilmiştir. Dördüncü senaryoda aynı verilerle VZA yönteminden elde edilen sonuçlar da kıyaslanmıştır. SSA yönteminin statik yapısından dolayı sonuçlar her bir ay için ayrı ayrı ve birbirinden bağımsız olarak yorumlanmalıdır. Bu bölümün sonunda ise 12 aylık ve 24 aylık etkinlik analizleri bütün senaryolar için bir arada verilmiştir. Analiz sonuçları yüzdelik oranları ifade etmektedir. Yüzdelik değerlerin ortalamasını almada kullanılan geometrik ortalama yöntemi bu sebeple her bir senaryo sonuçlarının türbinler bazında aylara göre ortalamasını hesap edebilmek için kullanılmıştır. Ay bazında türbinlerinin ortalaması (çiftliğinin genel ortalaması) ise analiz sonucunda bir çıktı olarak verildiği için geometrik ortalamaya ihtiyaç duyulmamıştır.

\subsection{Senaryo 1: Mekanik Hizlarla İlgili Girdi Verileri (Scenario 1: Mechanical Speed Related Input Data)}

Tablo 1, mekanik hız girdileri kullanılarak elde edilen bu senaryo modelinin istatistiksel olarak anlaml11ı düzeyi hakkında bilgiler sunmaktadır. En çok olabilirlik oran istatistiği (LR-loglikehood ratio) değerleri SSA analizi modellerinin sonucunda teknik etkinsizlik olup olmadığını test edebilmek için kullanılmaktadır. Bunun için $H_{0}: \lambda=0$; $H_{A}: \lambda>0$ hipotezlerinin incelenmesi gerekmektedir. LR istatistiği, Kodde-Palm tablo değerinden büyük olduğunda $H_{0}$ hipotezi reddedilir ve modelde istatistiksel olarak anlaml bir teknik etkinsizlik olduğu söylenebilir. Senaryo 1 için elde 
edilen LR değeri Tablo 1 görülmektedir. Sonuçlar 0,05 anlamlılık düzeyinde bir kısıtlamalı Kodde-Palm [50] tablo değeri olan 2,706 ile karşılaştırıldığında, LR değerlerinin tablo değerinden büyük olması durumunda hipotez reddedilir. Böylece sunulan senaryo 1 modeli anlamlıdır yorumu yapılır. Ayrıca, modelde elde edilen gama değerleri de etkinsizliğin rastlantısal hatalardan mi teknik etkinsizlikten mi kaynaklandığını yorumlamamızı sağlar. Diğer senaryolar için de yapılan analizlerde teknik etkinsizliğin olup olmaması için bu hipotez kullanılmış olup bütün modellerde verilerin SSA'ya uygun olduğu sonucuna varılmıştır. Modelin parametrik değerlerinin anlamlılığ tablo 1'deki t-değerleri ve buna karş1lık gelen p-değerleriyle açıklanır. Buna göre \%5'e göre anlamlılık sınamasında $H_{0}$ reddedilir ve tüm $\beta$ parametreleri anlamlıdır. Elde edilen sonuçlara göre, rotor hızındaki \%1'lik bir artış üretilen rüzgar gücünde yaklaşık \%173'lük azalışa, jeneratör hızındaki \%1'lik bir artış ise rüzgar gücünde yaklaşık olarak \%175'lik artışa sebep olmaktadır. Tablo 2'de ilk senaryo için ay bazında etkinlikler ve gama değerleri verilmiştir. En etkin türbin \%96 etkinlik skorlarıyla Türbin 3 ve Türbin 14 olarak gözlemlenmiştir. Türbin 12 de \%95'lik bir skorla en etkin ilk üç türbin arasında görülmektedir. Diğer taraftan Türbin 2 ve Türbin 7 \%14'lik etkinlik kayıplarıyla en etkinsiz türbinler olmuşlardır. En etkin türbinle en az etkin türbin arasındaki fark \%10'dur. Türbinler arasındaki etkinlik skorlarının istatistiksel olarak anlamlı bir farklılığa sahip olup olmadığ
ANOVA testi ile söylenebilir. Senaryo 1 sonuçlarının \%95 güven aralığında anlamlı olduğu Şekil 4'te gösterilmiştir. Bu sonuçlara göre benzer mekanik hızlara sahip türbinler arasında \%10'luk bir etkinlik farkı yaşanmış olup ortalama gama değerinden (\%95) bu etkinlik kaybının teknik etkinsizlikten kaynaklandığ 1 yorumu yapılabilmektedir.

Dolayısıyla, Türbin 2 ve Türbin 7'nin neden benzer jeneratör ve rotor hızlarında düşük performansla üretim gerçekleştirdiğinin araştırılması gerekmektedir. Ay bazında yapılmış olan bu analiz sonucuna göre mart ayında en yüksek etkinlik skoru gözlemlenmiş olup ağustos ve aralık aylarında ise en düşük etkinlikler görülmüştür. Bu sonuçlara göre ağustos ve aralık aylarındaki etkinsizliğin sebeplerinin jeneratör ve rotor hızları göz önünde bulundurularak mekanik bir arıza sebebi ile mi gerçekleştiği araştırılmalıdır. Elde edilen verilerde arıza kayıtları olmadığı için bu konu ileriki çalışmalara bırakılmıştır.

\subsection{Senaryo 2: Sicaklıklarla Illgili Girdi Verileri (Scenario 2: Temperature Related Input Data)}

Tablo 3'e göre LR değeri modelin anlamlı olduğunu açıklamaktadır. Parametreler incelendiğinde $\% 5$ 'e göre anlamlılık sinamasında $H_{0}$ reddedilir ve $\beta$ parametreleri anlamlıdır. Sadece $\beta_{4}$ için $\% 10$ 'e göre anlamlılık sınaması $\mathrm{H}_{0}$ reddedilir ve $\beta_{4}$ anlamlıdır.

Tablo 1. Senaryo 1 için analiz sonuçları anlamlılık testleri (Significance tests for the results of Scenario 1)

\begin{tabular}{llllll}
\hline Boş Hipotez & Parametre & Katsay1 Değerleri & Std, Sapmalar & t - değerleri & p değerleri \\
\hline $\mathrm{H}_{0}: \beta_{0}=0$ & $\beta_{0}$ & 808,94 & 0,96 & 842,32 & 0,00 \\
$\mathrm{H}_{0}: \beta_{1}=0$ & $\beta_{1}$ & $-173,32$ & 0,22 & $-784,76$ & 0,00 \\
$\mathrm{H}_{0}: \beta_{2}=0$ & $\beta_{2}$ & 175,28 & 0,34 & 518,82 & 0,00 \\
& $\delta^{2}$ & 0,00 & 0,00 & 2,37 & \\
& $\gamma$ & 1,00 & 0,01 & 184,56 & \\
& LR & 23,85 & & \\
\hline $\mathrm{p}<0.05(*) \% 5$ 'e göre anlaml1l1k sinamas1 $\mathrm{H}_{0}$ ret edilir ve $\beta$ parametresi anlamlidır.
\end{tabular}

Tablo 2. Senaryo 1 için elde edilen aylık etkinlikler (Monthly efficiencies according to Scenario 1)

\begin{tabular}{lllllllllllllll}
\hline & \multicolumn{11}{c}{ ETKİNLIK } \\
\cline { 2 - 7 } & 1 & 2 & 3 & 4 & 5 & 6 & 7 & 8 & 9 & 10 & 11 & 12 & Ortalama \\
\hline Türbin 1 & 0,89 & 0,90 & 0,95 & 1,00 & 0,96 & 0,94 & 0,99 & 0,83 & 0,89 & 0,98 & 0,87 & 0,83 & 0,92 \\
Türbin 2 & 0,86 & 0,88 & 0,91 & 0,85 & 0,80 & 0,88 & 0,79 & 0,80 & 0,85 & 1,00 & 0,80 & 0,85 & 0,86 \\
Türbin 3 & 1,00 & 0,99 & 1,00 & 0,96 & 0,97 & 0,99 & 0,90 & 0,99 & 1,00 & 0,95 & 0,95 & 0,84 & 0,96 \\
Türbin 4 & 0,98 & 0,98 & 0,99 & 0,99 & 0,95 & 0,93 & 0,87 & 0,83 & 0,91 & 0,97 & 0,90 & 0,87 & 0,93 \\
Türbin 5 & 0,96 & 0,90 & 0,96 & 0,87 & 0,90 & 0,87 & 0,75 & 0,77 & 0,82 & 0,83 & 1,00 & 0,84 & 0,87 \\
Türbin 6 & 0,92 & 0,84 & 0,94 & 0,92 & 0,96 & 1,00 & 0,76 & 0,76 & 0,92 & 0,85 & 0,73 & 0,82 & 0,87 \\
Türbin 7 & 0,89 & 0,82 & 0,92 & 0,93 & 0,89 & 0,95 & 0,76 & 0,75 & 0,87 & 0,86 & 0,80 & 0,87 & 0,86 \\
Türbin 8 & 0,86 & 0,81 & 0,92 & 0,92 & 0,91 & 0,86 & 0,80 & 0,81 & 0,91 & 0,94 & 0,93 & 0,85 & 0,88 \\
Türbin 9 & 0,99 & 0,97 & 0,96 & 0,85 & 0,90 & 0,93 & 0,90 & 0,86 & 0,83 & 0,97 & 0,79 & 0,84 & 0,90 \\
Türbin 10 & 0,87 & 0,90 & 1,00 & 0,90 & 0,95 & 0,82 & 0,94 & 0,84 & 0,88 & 0,83 & 0,84 & 0,83 & 0,88 \\
Türbin 12 & 0,94 & 0,98 & 0,99 & 0,98 & 0,96 & 0,96 & 0,94 & 0,94 & 0,94 & 0,98 & 0,97 & 0,88 & 0,95 \\
Türbin 13 & 0,96 & 1,00 & 0,99 & 0,92 & 0,94 & 0,95 & 0,88 & 0,86 & 0,87 & 0,90 & 0,98 & 0,88 & 0,93 \\
Türbin 14 & 0,97 & 0,97 & 0,98 & 0,98 & 0,98 & 1,00 & 1,00 & 1,00 & 0,94 & 0,88 & 0,91 & 0,87 & 0,96 \\
Türbin 16 & 0,96 & 0,90 & 0,94 & 0,96 & 0,93 & 0,92 & 0,90 & 0,84 & 0,91 & 0,92 & 0,88 & 0,91 & 0,91 \\
\hline Ortalama & 0,93 & 0,92 & 0,96 & 0,93 & 0,93 & 0,93 & 0,87 & 0,85 & 0,90 & 0,92 & 0,88 & 0,85 & 0,91 \\
\hline \multicolumn{1}{c}{$\gamma$} & 1,00 & 1,00 & 1,00 & 1,00 & 0,84 & 1,00 & 1,00 & 1,00 & 1,00 & 1,00 & 1,00 & 0,52 & 0,95 \\
\hline
\end{tabular}




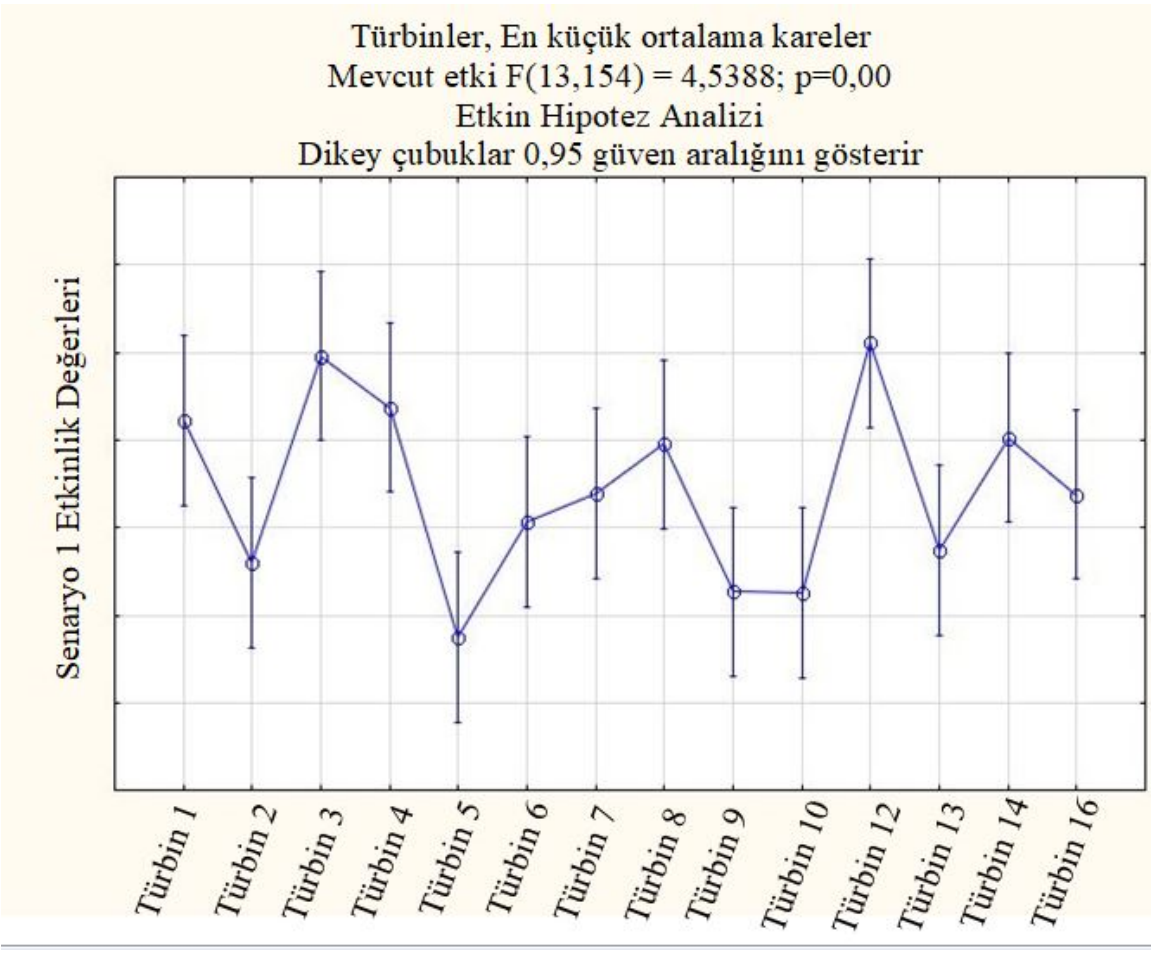

Şekil 4. Senaryo 1 için etkinlik değerlerinin ANOVA analizi (ANOVA of efficiency scores for Scenario 1)

Tablo 3. Senaryo 2 için analiz sonuçları anlamlılık testleri (Significance tests for the results of Scenario 2)

\begin{tabular}{|c|c|c|c|c|c|}
\hline Boş Hipotez & Parametre & Katsayı Değerleri & Std, Sapmalar & $\mathrm{t}$ - değerleri & $\mathrm{p}$ değerleri \\
\hline $\mathrm{H}_{0}: \beta_{0}=0$ & $\beta_{0}$ & $-12,38$ & 1,86 & $-6,64$ & $0,00^{*}$ \\
\hline $\mathrm{H}_{0}: \beta_{1}=0$ & $\beta_{1}$ & 0,74 & 0,24 & 3,09 & $0,00 *$ \\
\hline $\mathrm{H}_{0}: \beta_{2}=0$ & $\beta_{2}$ & 2,18 & 0,69 & 3,14 & $0,00 *$ \\
\hline $\mathrm{H}_{0}: \beta_{3}=0$ & $\beta_{3}$ & 1,33 & 0,66 & 2,00 & $0,03 *$ \\
\hline $\mathrm{H}_{0}: \beta_{4}=0$ & $\beta_{4}$ & 0,71 & 0,49 & 1,46 & $0,08 * *$ \\
\hline $\mathrm{H}_{0}: \beta_{5}=0$ & $\beta_{5}$ & 2,11 & 0,67 & 3,16 & $0,00^{*}$ \\
\hline \multirow[t]{4}{*}{$\mathrm{H}_{0}: \beta_{6}=0$} & $\beta_{6}$ & $-1,87$ & 0,50 & $-3,74$ & $0,00^{*}$ \\
\hline & $\delta^{2}$ & 0,01 & 0,03 & & \\
\hline & $\gamma$ & 0,03 & 4,09 & & \\
\hline & LR & 12,89 & & & \\
\hline
\end{tabular}

Elde edilen sonuçlara göre, jeneratör rulman sıcaklığındaki \%1'lik bir artış üretilen güçte \%0,74'lük bir artışa; hidrolik yă̆ sıcaklığındaki \%1'lik bir artış üretilen güçte \%2,18'lik bir artışa; motor yeri sıcaklığındaki \%1'lik bir artış üretilen güçte \%1,33'lük artışa; şebeke bağlantı yerinin sıcaklığındaki \%1'lik bir artış üretilen güçte \%0,71'lik artışa; kontrol merkezi sıcaklığındaki \%1'lik bir artış üretilen güçte 2,11 'lik artışa ve spiner sıcaklığındaki \%1'lik bir artış üretilen güçte \%1,87'lik azalışa sebep olmaktadır. Bu senaryodan da anlaşıldığı üzere sıcak parametrelerinin üretilen güç üzerindeki etkisi mekanik hız parametrelerinden oldukça düşüktür. Bu senaryo için elde edilen sonuçlar Tablo 4'de gösterilmiştir. Gerçekleşen etkinlik skorlarına göre Türbin 4 ve Türbin 12 en etkin türbinler olurken Türbin 10 etkinliği en düşük türbin olmuştur. En düşük ve en yüksek etkinlik skorları arasındaki fark \%24 ile ilk senaryoya göre oldukça yüksektir. Aralık \%99 etkinlik skoru ile en etkin ay olurken ekim \%83 ile etkinliği en düşük ay olmuştur. Senaryo 2'nin etkinlik skorları arasında anlamlı bir farklılık olduğu da ANOVA sonuçlarının bulunduğu Şekil 5'ten görülebilir.

\subsection{Senaryo 3: Rüzgâr ile Ilgili Girdi Verileri (Scenario 3: Wind Related Input Data)}

Senaryo 3 için oluşturan model Tablo 5'de bulunan LR değerine göre anlamlı olup, parametrelerden sadece $\beta_{0}$ için $\% 5$ 'e göre anlamlılık sınaması $\mathrm{H}_{0}$ reddedilir ve $\beta_{0}$ anlamlıdır. $\beta_{3}$ için ise \%10'a göre anlamlılık sınaması $H_{0}$ reddedilir ve $\beta_{3}$ anlamlıdır. Diğer parametrelerin etkinsizlik tespiti için bir 
Akalın ve ark. / Journal of the Faculty of Engineering and Architecture of Gazi University 32:4 (2017) 1311-1325

Tablo 4. Senaryo 2 için elde edilen aylık etkinlikler (Monthly efficiencies according to Scenario 2)

\begin{tabular}{lllllllllllllll}
\hline & \multicolumn{11}{c}{ ETKİNLIK } \\
\cline { 2 - 7 } & 1 & 2 & 3 & 4 & 5 & 6 & 7 & 8 & 9 & 10 & 11 & 12 & Ortalama \\
\hline Türbin 1 & 0,83 & 0,80 & 0,84 & 0,74 & 0,99 & 0,99 & 0,99 & 0,95 & 0,97 & 0,91 & 0,98 & 0,99 & 0,92 \\
Türbin 2 & 0,87 & 0,86 & 0,89 & 0,94 & 0,98 & 0,95 & 0,87 & 0,87 & 0,85 & 0,92 & 0,87 & 0,99 & 0,90 \\
Türbin 3 & 0,84 & 0,85 & 0,87 & 0,71 & 0,82 & 0,92 & 0,95 & 0,89 & 0,83 & 0,66 & 0,76 & 0,99 & 0,84 \\
Türbin 4 & 0,88 & 0,99 & 0,98 & 0,97 & 0,98 & 0,97 & 0,94 & 0,95 & 0,93 & 1,00 & 0,99 & 0,99 & 0,96 \\
Türbin 5 & 0,89 & 0,98 & 1,00 & 0,94 & 0,99 & 0,98 & 0,98 & 0,99 & 1,00 & 0,87 & 0,83 & 0,99 & 0,95 \\
Türbin 6 & 0,81 & 0,80 & 0,78 & 0,96 & 0,91 & 0,91 & 0,91 & 0,91 & 0,80 & 0,71 & 0,74 & 0,99 & 0,85 \\
Türbin 7 & 0,81 & 0,75 & 0,78 & 0,77 & 0,83 & 0,88 & 0,91 & 0,91 & 0,71 & 0,70 & 0,72 & 0,99 & 0,81 \\
Türbin 8 & 0,84 & 0,80 & 0,83 & 0,87 & 0,93 & 0,89 & 0,82 & 0,83 & 0,74 & 0,73 & 0,90 & 0,99 & 0,85 \\
Türbin 9 & 0,89 & 0,89 & 0,93 & 0,85 & 0,82 & 0,92 & 0,94 & 0,95 & 0,80 & 0,80 & 0,93 & 0,99 & 0,89 \\
Türbin 10 & 0,84 & 0,72 & 0,81 & 0,51 & 0,65 & 0,74 & 0,75 & 0,66 & 0,66 & 0,62 & 0,72 & 0,99 & 0,72 \\
Türbin 12 & 0,87 & 0,99 & 0,98 & 0,90 & 0,99 & 0,99 & 0,98 & 0,99 & 0,97 & 0,93 & 0,89 & 0,99 & 0,96 \\
Türbin 13 & 0,91 & 1,00 & 0,99 & 1,00 & 0,94 & 0,88 & 0,91 & 0,84 & 0,78 & 1,00 & 0,96 & 0,99 & 0,93 \\
Türbin 14 & 0,84 & 0,75 & 0,80 & 0,81 & 0,96 & 0,92 & 0,96 & 0,85 & 0,89 & 1,00 & 0,94 & 0,99 & 0,89 \\
Türbin 16 & 0,84 & 0,78 & 0,85 & 0,82 & 0,99 & 0,96 & 0,98 & 0,99 & 0,87 & 0,74 & 0,69 & 0,99 & 0,87 \\
\hline Ortalama & 0,85 & 0,85 & 0,88 & 0,84 & 0,91 & 0,92 & 0,92 & 0,90 & 0,84 & 0,83 & 0,85 & 0,99 & 0,88 \\
\hline$\gamma$ & 0,53 & 1,00 & 1,00 & 1,00 & 0,95 & 0,98 & 1,00 & 1,00 & 1,00 & 1,00 & 0,99 & 0,03 & 0,87 \\
\hline
\end{tabular}

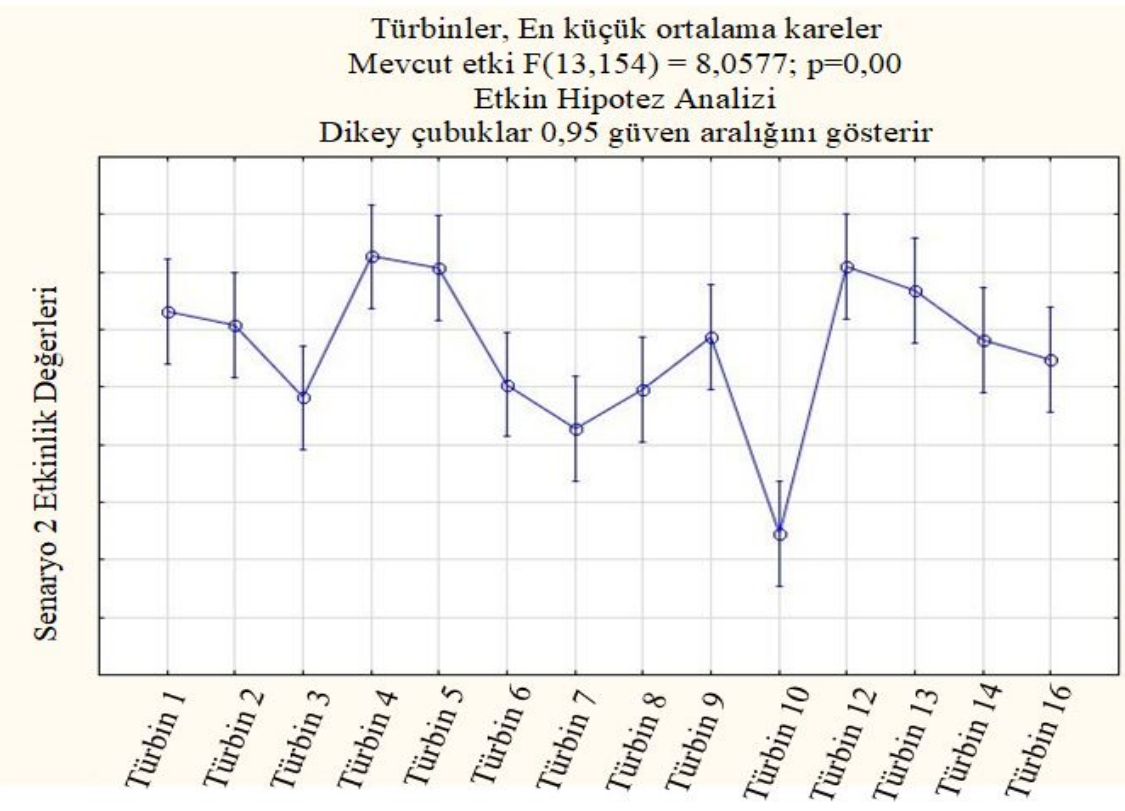

Şekil 5. Senaryo 2 için etkinlik değerlerinin ANOVA analizi (ANOVA of efficiency scores for Scenario 2)

anlam ifade etmediği söylenebilir. Tablo 6'da bu senaryoya ait gözlemlenen etkinlik skorları verilmiştir. Türbin 4 ve Türbin 7 en etkin türbin olarak gözlemlenmesine rağmen Türbin 5 en düşük etkinliğe sahip olan türbindir.

İlk iki senaryoya göre Senaryo 3'ün sonuçları \%5 ile oldukça düşük etkinlik aralığına sahiptir. Bu senaryo için Türbinlerin tamamının \%90'ın üzerinde etkinlik skorları vardır. Diğer taraftan ocak en etkin ay iken nisan $\% 87$ ile en düşük etkinliğe sahiptir. Fakat etkinlik düzeylerinin arasında anlamlı bir fark olmadığı ANOVA sonucunda görülmüştür (Şekil 6). Dolayısıyla bu senaryonun rüzgar türbinlerinde etkinlik kıyaslanması yapılırken kritik önem taşımadığı ve parametrik olarak da anlamlı olmadığı söylenebilir.

\subsection{Senaryo 4: Karma Girdi Verileri (Scenario 4: Mixed Input Data)}

Daha önce VZA'da kullanılmış girdi ve çıktı parametrelerinin olduğu bu model LR testine göre anlamlı olduğu Tablo 7'de görülmektedir. Girdi parametrelerinin tamamı için $\% 5$ 'e göre anlamlılık sınamas $1 H_{0}$ reddedilir ve $\beta$ parametreleri anlamlıdır. Elde edilen sonuçlara göre; jeneratör hızındaki \%1'lik bir artış üretilen güçte \%127'lik azalışa, rotor hızındaki \%1'lik bir artış üretilen güçte $\% 128$ 'lik artışa ve rüzgar hızındaki \%1'lik bir artış üretilen güçte \%1,08'lik artışa sebep olmuştur. Mekanik hızların modellendiği senaryo 1'deki parametre katsay1ları kıyaslandığında rotor hızının ve jeneratör hızının üretilen güçteki etkisi bu senaryoyla paralellik göstermektedir. 
Tablo 5. Senaryo 3 için analiz sonuçları anlamlılık testleri (Significance tests for the results of Scenario 3)

\begin{tabular}{|c|c|c|c|c|c|}
\hline Boş Hipotez & Parametre & Katsayı Değerleri & Std, Sapmalar & $\mathrm{t}$ - değerleri & $\mathrm{p}$ değerleri \\
\hline $\mathrm{H}_{0}: \beta_{0}=0$ & $\beta_{0}$ & 3,46 & 1,18 & 2,93 & $0,01^{*}$ \\
\hline $\mathrm{H}_{0}: \beta_{1}=0$ & $\beta_{1}$ & 0,58 & 0,93 & 0,62 & $0,27 * * *$ \\
\hline $\mathrm{H}_{0}: \beta_{2}=0$ & $\beta_{2}$ & $-0,18$ & 0,80 & $-0,22$ & $0,41 * * *$ \\
\hline $\mathrm{H}_{0}: \beta_{3}=0$ & $\beta_{3}$ & 0,75 & 0,45 & 1,67 & $0,06^{* *}$ \\
\hline \multirow[t]{4}{*}{$\mathrm{H}_{0}: \beta_{4}=0$} & $\beta_{4}$ & 0,30 & 0,25 & 1,18 & $0,13 * * *$ \\
\hline & $\delta^{2}$ & 0,00 & 0,00 & 1,94 & \\
\hline & $\gamma$ & 1,00 & 0,01 & 198,39 & \\
\hline & LR & 38,02 & & & \\
\hline \multicolumn{6}{|c|}{$\mathrm{p}<0,05\left(^{*}\right) \% 5^{\prime}$ e göre anlamlılık sınaması $\mathrm{H}_{0}$ ret edilir ve $\beta$ parametresi anlamlıdır. } \\
\hline \multicolumn{6}{|c|}{$\mathrm{p}<0,10(* *) \% 10$ 'a göre anlamlılık sınaması $\mathrm{H}_{0}$ ret edilir ve $\beta$ parametreleri anlamlıdır. } \\
\hline \multicolumn{6}{|c|}{$\mathrm{p}>0,05(* * *) \% 5$ 'e göre anlamlılık sınaması $\mathrm{H}_{0}$ kabul edilir ve $\beta$ parametresi anlamlı değildir. } \\
\hline
\end{tabular}

Tablo 6. Senaryo 3 için elde edilen aylık etkinlikler (Monthly efficiencies according to Scenario 3)

\begin{tabular}{llllllllllllll}
\hline & \multicolumn{11}{c}{ ETKİNLIK } \\
\hline Türbin / Ay & 1 & 2 & 3 & 4 & 5 & 6 & 7 & 8 & 9 & 10 & 11 & 12 & Ortalama \\
\hline Türbin 1 & 0,98 & 0,93 & 0,96 & 0,91 & 0,99 & 0,96 & 0,97 & 0,96 & 0,97 & 0,92 & 0,96 & 0,96 & 0,96 \\
Türbin 2 & 1,00 & 0,98 & 0,99 & 0,79 & 0,95 & 1,00 & 1,00 & 0,99 & 0,98 & 0,85 & 0,97 & 0,97 & 0,95 \\
Türbin 3 & 0,99 & 0,83 & 0,97 & 0,84 & 0,95 & 0,99 & 0,99 & 0,98 & 0,98 & 0,97 & 0,98 & 0,97 & 0,95 \\
Türbin 4 & 0,98 & 0,94 & 0,96 & 0,91 & 1,00 & 1,00 & 0,99 & 1,00 & 0,99 & 1,00 & 0,97 & 0,97 & 0,97 \\
Türbin 5 & 0,95 & 0,94 & 0,89 & 0,83 & 0,91 & 0,91 & 0,94 & 0,93 & 0,95 & 0,88 & 0,96 & 0,96 & 0,92 \\
Türbin 6 & 0,95 & 0,91 & 0,92 & 0,93 & 0,96 & 0,94 & 0,98 & 1,00 & 0,97 & 0,89 & 0,96 & 0,95 & 0,95 \\
Türbin 7 & 0,94 & 0,92 & 0,97 & 1,00 & 0,98 & 1,00 & 0,98 & 0,99 & 0,98 & 1,00 & 0,98 & 0,95 & 0,97 \\
Türbin 8 & 1,00 & 0,97 & 0,98 & 0,75 & 0,97 & 0,97 & 0,99 & 1,00 & 0,97 & 0,89 & 0,94 & 0,96 & 0,95 \\
Türbin 9 & 0,99 & 1,00 & 0,98 & 0,78 & 0,91 & 0,95 & 0,97 & 1,00 & 0,96 & 0,93 & 0,96 & 0,96 & 0,95 \\
Türbin 10 & 0,99 & 1,00 & 1,00 & 0,81 & 0,91 & 0,89 & 0,92 & 0,91 & 0,91 & 0,86 & 0,96 & 0,98 & 0,93 \\
Türbin 12 & 1,00 & 0,97 & 0,97 & 0,88 & 0,96 & 0,96 & 0,97 & 0,96 & 0,97 & 0,90 & 0,96 & 0,97 & 0,96 \\
Türbin 13 & 0,99 & 0,89 & 0,96 & 0,91 & 0,87 & 0,92 & 0,91 & 0,87 & 0,95 & 0,95 & 0,97 & 0,96 & 0,93 \\
Türbin 14 & 0,98 & 0,98 & 0,99 & 1,00 & 0,92 & 0,95 & 0,97 & 0,90 & 0,93 & 0,82 & 0,96 & 0,96 & 0,95 \\
Türbin 16 & 0,95 & 0,92 & 0,96 & 0,84 & 0,99 & 0,98 & 0,96 & 0,99 & 0,98 & 1,00 & 0,97 & 0,94 & 0,96 \\
\hline Ortalama & 0,98 & 0,94 & 0,96 & 0,87 & 0,95 & 0,96 & 0,97 & 0,96 & 0,96 & 0,92 & 0,96 & 0,96 & 0,95 \\
\hline$\gamma$ & 0,98 & 1,00 & 1,00 & 1,00 & 1,00 & 1,00 & 1,00 & 1,00 & 0,73 & 1,00 & 0,50 & 0,50 & 0,89 \\
\hline
\end{tabular}

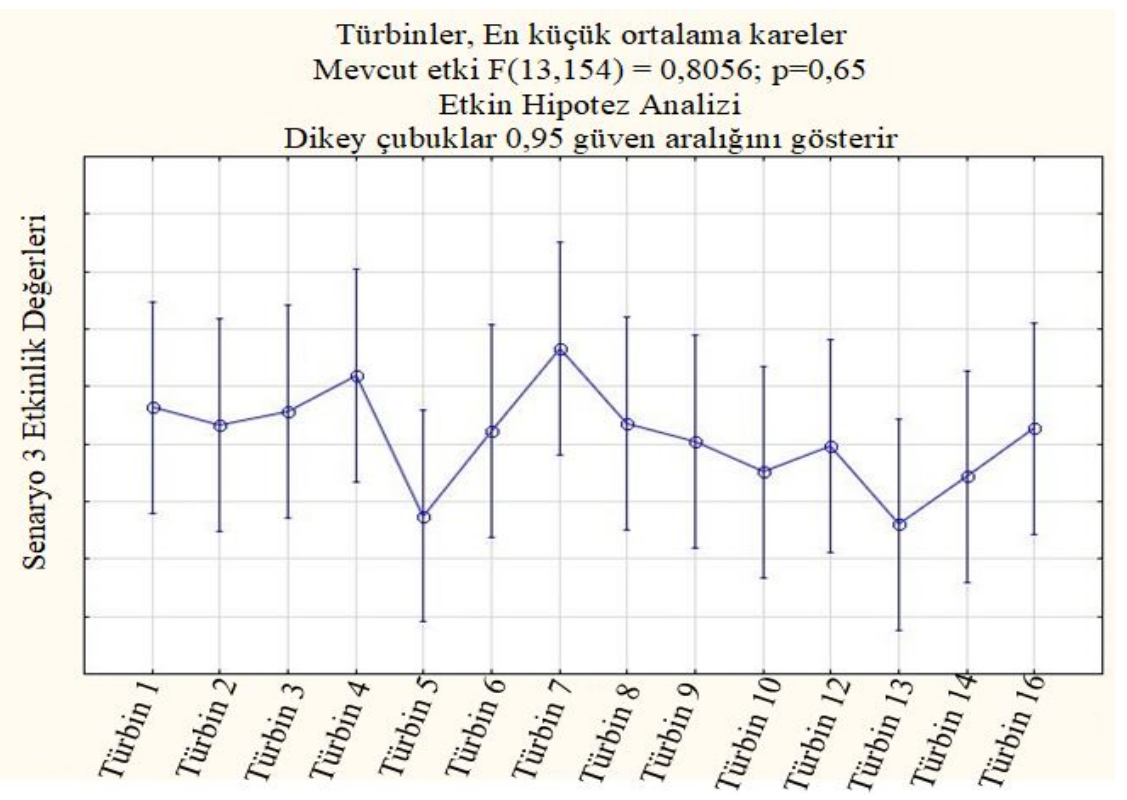

Şekil 6. Senaryo 3 için etkinlik değerlerinin ANOVA analizi (ANOVA of efficiency scores for Scenario 3) 
Analiz sonucunda karma girdilerle oluşturulmuş modelde etkinlik skorları Tablo 8'de verilmiştir. Türbin 3 ve Türbin $12 \% 98$ ile en etkin türbinler olurken Türbin 5 ve Türbin 10 sırasıyla en düşük türbinler olmuştur. Ocak ve mart ayları bu yıl için en yüksek etkinliğe sahip aylardır. Diğer taraftan $\% 92$ etkinlik skoru ile eylül en düşük etkinliğe sahiptir. Senaryo 3'te olduğu gibi bu senaryoda da her iki yıl için de en yüksek ve en düşük etkinlik skorları arasındaki fark \%7 civarındadır. Şekil 7'de görüldüğü üzere bu senaryo çıktıları için etkinlik skorları anlamlı bir farklılık göstermiştir. SSA ve VZA modelleri teknik etkinlik analiz yöntemleri arasında sıkl1kla kullanılan yöntemlerdir. Her iki yöntemin de birbirlerine göre üstünlükleri ve eksiklikleri bulunmaktadır. VZA parametre bağımsız bir yaklaşımdır. Eroğlu ve Seçkiner'in [3] çalışmasında rüzgar türbinlerinin etkinlik skorlarının tespiti ve kıyaslanması çalışılmıştır.

Fakat, etkinsizliğin VZA modeli gereği parametrik incelenmesi yapılmamıştır. SSA yaklaşımı ise parametrik özelliği sayesinde teknik etkinliğin hangi parametreye ne oranda bağımlı olduğu konusunda fikir sunabilmektedir. Ayrıca, VZA sonucunda etkinsizlik oranının istatistiksel sapmadan mi yoksa etkinsizlikten mi kaynaklandığ 1 konusunda bir fikir vermez ve doğrudan etkinsizlik skorunu verir. SSA ise gama parametresi sayesinde istatistiksel hata veya etkinsizlik konusunda yorum yapabilmeyi sağlar. VZA ile yapılan çalışma [3] kıyaslandığında SSA ile yapılmış olan bu çalışmada daha yüksek etkinlik skorları elde edildiği gözlemlenmektedir. VZA sonuçları \%69 - \%98 etkinlik seviyeleri sunarken SSA aynı senaryo için \%90'ın üzerinde skorlar vermiştir. Jacobs vd. [51] SSA'nın VZA'dan daha yüksek skorlar verdiğini raporlamışlardır. Her iki analizin de farklı sonuçlar vermesi analizlerin yapısı gereği beklenen bir durumdur. Buna rağmen hem SSA sonuçlarında hem de VZA sonuçlarında Türbin 10 en düşük performansa sahip türbinler arasında yer almıştır. Bu da her ne kadar farklı skorlar vermiş olsalar da iki farklı yöntemin etkinsizliği en yüksek olan türbini aynı seçmeleri bu türbin ile ilgili detaylı analizlerin yapılması gerektiğini göstermektedir. Tablo 9'da bütün senaryolar için sırasıyla ilk yıl ve ikinci yılda gerçekleşen 12 aylık ortalama etkinlik skorları görülmektedir. İkinci senaryo haricinde genelde etkinlik skor ortalamaları \%90 civarında gerçekleşirken Senaryo 2'nin ortalama etkinlik skorları birinci ve ikinci yıllar için sırasıyla $\% 76$ ve $\% 78$ olarak gözlemlenmiştir. Bununla beraber, Senaryo 2'nin gama değerleri de diğer tüm senaryolardan oldukça yüksek çıkmış olup neredeyse etkinlik kayıplarının \%70'i teknik etkinsizlik geri kalan \%30'luk k1smı ise istatiksel sapmalardan kaynaklandığı sonucuna varılabilir. Diğer taraftan, ilk senaryodaki etkinlik kayıplarının yarısı istatiksel sapmadan diğer yarısı teknik etkinsizlikten olduğu, üçüncü senaryonun ilk y1l için \%23'ü teknik etkinsizlikten

Tablo 7. Senaryo 4 için analiz sonuçları anlamlılık testleri (Significance tests for the results of Scenario 4)

\begin{tabular}{llllll}
\hline Boş Hipotez & Parametre & Katsay1 Değerleri & Std, Sapmalar & t - değerleri & p değerleri \\
\hline $\mathrm{H}_{0}: \beta_{0}=0$ & $\beta_{0}$ & 597,93 & 0,99 & 604,56 & $0,00^{*}$ \\
$\mathrm{H}_{0}: \beta_{1}=0$ & $\beta_{1}$ & $-127,91$ & 0,31 & $-406,18$ & $0,00^{*}$ \\
$\mathrm{H}_{0}: \beta_{2}=0$ & $\beta_{2}$ & 128,82 & 0,95 & 135,78 & $0,00^{*}$ \\
$\mathrm{H}_{0}: \beta_{3}=0$ & $\beta_{3}$ & 1,08 & 0,17 & 6,37 & $0,00^{*}$ \\
& $\delta^{2}$ & 0,00 & 0,00 & 2,86 & \\
& $\gamma$ & 1,00 & 0,12 & 8,17 & \\
& LR & 35,41 & & \\
\hline p $<0.05\left(^{*}\right) \% 5^{\prime}$ 'e göre anlamlılık sinamas1 $\mathrm{H}_{0}$ ret edilir ve $\beta$ parametresi anlamlıdır. \\
\hline
\end{tabular}

Tablo 8. Senaryo 4 için elde edilen aylık etkinlikler (Monthly efficiencies according to Scenario 4)

\begin{tabular}{|c|c|c|c|c|c|c|c|c|c|c|c|c|c|}
\hline \multicolumn{14}{|l|}{ ETKİNLİK } \\
\hline Türbin / Ay & 1 & 2 & 3 & 4 & 5 & 6 & 7 & 8 & 9 & 10 & 11 & 12 & Ortalama \\
\hline Türbin 1 & 0,99 & 1,00 & 0,99 & 0,98 & 1,00 & 0,97 & 0,98 & 0,92 & 0,90 & 0,99 & 0,91 & 0,95 & 0,96 \\
\hline Türbin 2 & 0,93 & 0,94 & 0,95 & 0,88 & 0,90 & 0,92 & 0,94 & 1,00 & 0,90 & 0,96 & 0,91 & 0,95 & 0,93 \\
\hline Türbin 3 & 0,99 & 0,94 & 0,99 & 0,91 & 0,98 & 1,00 & 0,99 & 0,99 & 0,99 & 0,98 & 0,99 & 1,00 & 0,98 \\
\hline Türbin 4 & 1,00 & 0,99 & 1,00 & 0,95 & 0,94 & 0,96 & 0,97 & 0,95 & 0,93 & 0,97 & 0,99 & 0,97 & 0,97 \\
\hline Türbin 5 & 0,94 & 0,95 & 0,94 & 0,92 & 0,88 & 0,89 & 0,93 & 0,92 & 0,85 & 0,90 & 0,95 & 0,92 & 0,91 \\
\hline Türbin 6 & 0,95 & 0,92 & 0,94 & 0,98 & 0,97 & 0,98 & 0,95 & 0,96 & 0,92 & 0,94 & 0,87 & 0,92 & 0,94 \\
\hline Türbin 7 & 0,94 & 0,90 & 0,97 & 0,90 & 0,94 & 1,00 & 0,95 & 0,96 & 0,90 & 0,96 & 1,00 & 0,96 & 0,95 \\
\hline Türbin 8 & 0,97 & 0,94 & 0,98 & 0,93 & 0,98 & 0,94 & 1,00 & 0,99 & 0,93 & 0,97 & 0,93 & 0,95 & 0,96 \\
\hline Türbin 9 & 0,98 & 0,98 & 0,98 & 0,87 & 0,89 & 0,93 & 0,95 & 0,95 & 0,84 & 0,95 & 0,87 & 0,92 & 0,93 \\
\hline Türbin 10 & 0,97 & 0,99 & 1,00 & 0,97 & 0,89 & 0,85 & 0,94 & 0,86 & 0,86 & 0,89 & 0,91 & 0,96 & 0,92 \\
\hline Türbin 12 & 0,97 & 1,00 & 0,99 & 0,98 & 0,99 & 0,98 & 0,99 & 1,00 & 1,00 & 0,98 & 0,95 & 0,95 & 0,98 \\
\hline Türbin 13 & 0,98 & 0,98 & 0,97 & 0,94 & 0,89 & 0,92 & 0,90 & 0,86 & 0,91 & 0,96 & 1,00 & 0,92 & 0,93 \\
\hline Türbin 14 & 0,98 & 0,99 & 0,98 & 0,98 & 0,97 & 0,99 & 0,98 & 0,93 & 0,97 & 0,93 & 0,91 & 0,91 & 0,96 \\
\hline Türbin 16 & 0,98 & 0,96 & 0,95 & 0,99 & 0,95 & 0,93 & 0,91 & 0,92 & 0,93 & 0,96 & 0,95 & 0,95 & 0,95 \\
\hline Ortalama & 0,97 & 0,96 & 0,97 & 0,94 & 0,94 & 0,95 & 0,96 & 0,94 & 0,92 & 0,95 & 0,94 & 0,94 & 0,95 \\
\hline$\gamma$ & 1,00 & 1,00 & 1,00 & 0,95 & 1,00 & 1,00 & 1,00 & 1,00 & 1,00 & 0,82 & 1,00 & 1,00 & 0,98 \\
\hline
\end{tabular}




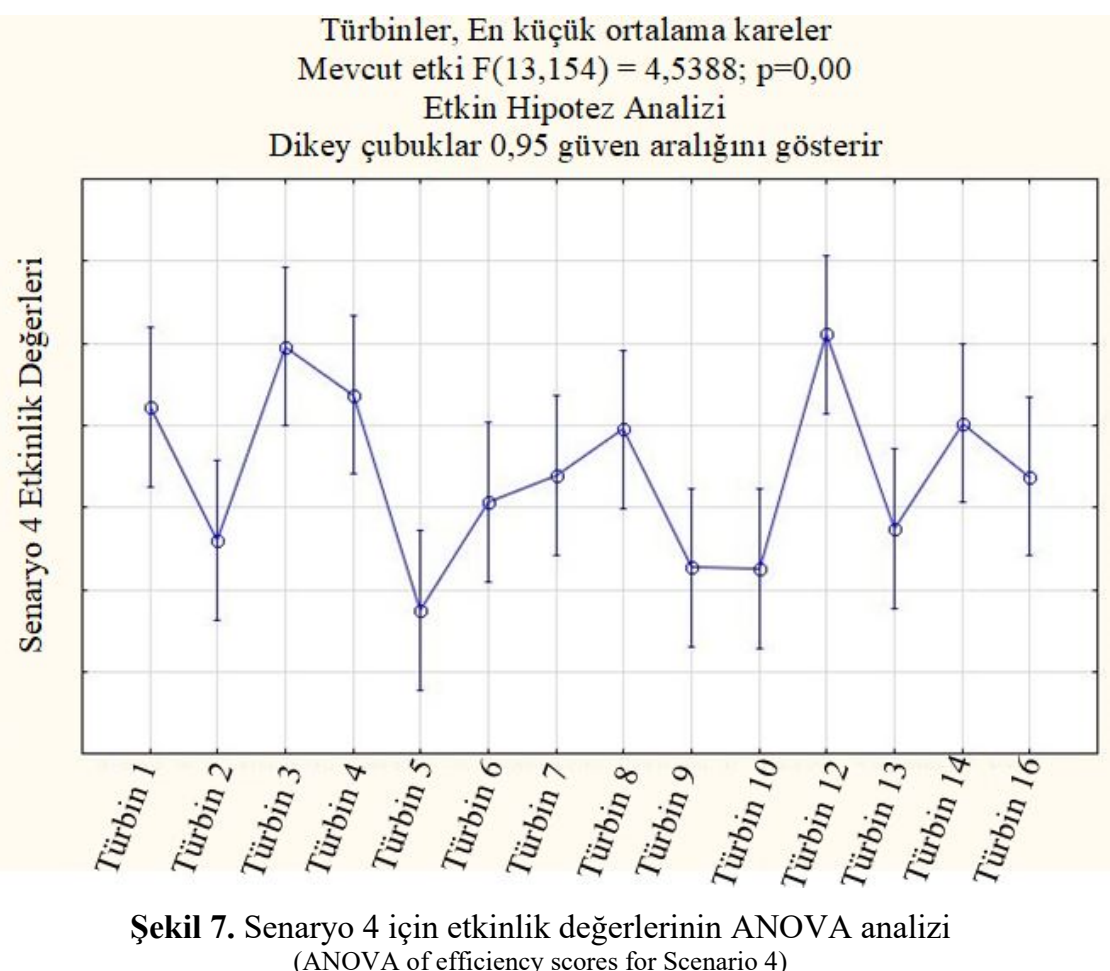

Tablo 9. Bütün senaryolar için 12 aylık ortalama etkinlikler (Averaged 12 - month efficiencies according to all scenarios)

\begin{tabular}{|c|c|c|c|c|c|c|c|c|}
\hline & \multicolumn{8}{|c|}{ ETKİNLİK } \\
\hline & \multicolumn{2}{|c|}{ SENARYO 1} & \multicolumn{2}{|c|}{ SENARYO 2} & \multicolumn{2}{|c|}{ SENARYO 3} & \multicolumn{2}{|c|}{ SENARYO 4} \\
\hline & İlk y1l & İkinci yıl & İlk y1l & İkinci y1l & İlk y1l & İkinci y1l & İlk y1l & İkinci y1l \\
\hline Türbin 1 & 0,86 & 0,91 & 0,71 & 0,52 & 0,98 & 0,97 & 0,99 & 0,95 \\
\hline Türbin 2 & 0,86 & 0,89 & 0,88 & 0,89 & 0,99 & 0,99 & 0,98 & 0,96 \\
\hline Türbin 3 & 0,86 & 0,94 & 0,87 & 0,79 & 0,98 & 0,95 & 0,99 & 0,99 \\
\hline Türbin 4 & 0,92 & 0,97 & 0,85 & 0,75 & 0,99 & 0,98 & 0,99 & 0,99 \\
\hline Türbin 5 & 0,85 & 0,89 & 0,96 & 0,96 & 0,95 & 0,96 & 0,96 & 0,96 \\
\hline Türbin 6 & 0,83 & 0,84 & 0,86 & 0,95 & 0,96 & 0,91 & 0,97 & 0,93 \\
\hline Türbin 7 & 0,82 & 0,82 & 0,73 & 0,82 & 0,97 & 0,90 & 0,98 & 0,92 \\
\hline Türbin 8 & 0,81 & 0,81 & 0,67 & 0,56 & 0,96 & 0,95 & 0,98 & 0,96 \\
\hline Türbin 9 & 0,85 & 0,88 & 0,95 & 0,84 & 0,98 & 0,97 & 0,97 & 0,93 \\
\hline Türbin 10 & 0,77 & 0,79 & 0,60 & 0,61 & 0,95 & 0,94 & 0,96 & 0,91 \\
\hline Türbin 12 & 0,97 & 0,97 & 0,57 & 0,87 & 0,97 & 0,95 & 0,99 & 0,98 \\
\hline Türbin 13 & 0,97 & 0,96 & 0,61 & 0,91 & 0,96 & 0,94 & 0,97 & 0,96 \\
\hline Türbin 14 & 0,98 & 0,97 & 0,62 & 0,62 & 0,95 & 0,91 & 0,98 & 0,96 \\
\hline Türbin 16 & 0,93 & 0,96 & 0,76 & 0,76 & 0,99 & 0,99 & 0,98 & 0,99 \\
\hline Ortalama & 0,88 & 0,90 & 0,76 & 0,78 & 0,97 & 0,95 & 0,98 & 0,96 \\
\hline$\gamma$ & 0,52 & 0,53 & 0,70 & 0,73 & 0,23 & 0,46 & 0,11 & 0,38 \\
\hline
\end{tabular}

\%77'si istatiksel sapmadan ikinci y1lda ise sapmaların yaklaşık yarısının istatiksel hatadan diğer kalanının ise teknik etkinsizlikten kaynaklı olduğu yorumlanabilir. Son senaryo için de benzer şekilde ilk yıl oluşan etkinsizlik değerinin \%11'i teknik etkinsizlikten \%89'u ise istatiksel sapmadan olduğu söylenebilirken ikinci y1l için \%62'si istatiksel sapmadan \%38'i ise teknik etkinsizlikten kaynaklanmıştır. İki yıllık verilerin analiz sonuçları Tablo 10 'da verilmiştir. Tablodan da görüldüğü üzere her senaryo için en etkin türbin farklı bir türbindir. Fakat en düşük etkinliğe sahip türbinler incelendiğinde Türbin 10 bütün senaryolarda en düşük etkinliğe sahip üç türbin arasındadır. $\mathrm{Bu}$ durumda Türbin 10'un hangi girdilerle incelenirse incelensin performans kaybı yaşadığına işaret etmektedir. Özetlemek gerekirse, bu bölümde rüzgâr çiftliklerinde türbin performanslarının aylık, 12 aylık ve 24 aylık olmak üzere farklı zaman periyotlarında farklı girdi türleriyle incelenmiştir. Çalışma sonuçları kısa dönemli analizlerin uzun dönemli analizlerden daha hassas sonuçlar verdiğini göstermiştir. Günümüzde hızla artan rüzgâr çiftliklerinde türbinlerin sağlıklı çalışıp çalışmadığını izlemek ve kontrol etmek işletme ve bakım maliyetlerini en aza indirebilmek 
Tablo 10. Bütün senaryolar için 24 aylık ortalama etkinlikler (Averaged 24 - month efficiencies according to all scenarios)

\begin{tabular}{lllll}
\hline & ETKINLIK & & & \\
\cline { 2 - 5 } & SENARYO 1 & SENARYO 2 & SENARYO 3 & SENARYO 4 \\
\hline Türbin 1 & 0,85 & 0,51 & 0,96 & 0,97 \\
Türbin 2 & 0,86 & 0,93 & 0,99 & 0,96 \\
Türbin 3 & 0,86 & 0,79 & 0,94 & 0,99 \\
Türbin 4 & 0,93 & 0,84 & 0,98 & 0,99 \\
Türbin 5 & 0,84 & 0,97 & 0,93 & 0,95 \\
Türbin 6 & 0,81 & 0,90 & 0,91 & 0,94 \\
Türbin 7 & 0,79 & 0,76 & 0,91 & 0,95 \\
Türbin 8 & 0,79 & 0,55 & 0,93 & 0,97 \\
Türbin 9 & 0,83 & 0,92 & 0,96 & 0,95 \\
Türbin 10 & 0,75 & 0,53 & 0,92 & 0,92 \\
Türbin 12 & 0,98 & 0,61 & 0,94 & 0,99 \\
Türbin 13 & 0,97 & 0,71 & 0,93 & 0,96 \\
Türbin 14 & 0,98 & 0,59 & 0,90 & 0,97 \\
Türbin 16 & 0,93 & 0,58 & 0,99 & 0,99 \\
\hline Ortalama & 0,87 & 0,73 & 0,94 & 0,96 \\
\hline$\gamma$ & 0,60 & 0,74 & 0,50 & 0,25 \\
\hline
\end{tabular}

için önemli bir konudur. Bu çalışmada sunulduğu gibi etkinlik analiz yöntemleri daha kısa periyotlarda da uygulanarak (haftalık, günlük, vb.) etkinlik düşüşleri çeşitli parametrelerle gözlemlenip takip edilebilir ve böylece önleyici bakım planları yapılabilir.

\section{SONUÇLAR (CONCLUSIONS)}

$\mathrm{Bu}$ çalışmada SSA yöntemi 10-dakikalık ortalamalarla SCADA sisteminde tutulan çeşitli verilerle modellenerek farklı zaman periyotlarında rüzgâr türbinlerinin etkinlik analizleri incelenmiştir. İlk olarak sistemden alınan ham veriler aylık ortalamalara dönüştürülmüş daha sonra da türbinlerin çeşitli girdi grupları arasında nasıl etkinlik skorları verecekleri gözlemlenmesi için dört farklı senaryo oluşturulmuştur. Böylece mekanik hızla ilgili parametrelerin, sıcaklıkla ilgili parametrelerin, rüzgâr hızı ile ilgili parametrelerin ve karma parametrelerin etkinlik sonuçlarında ne gibi değişikliklere sahip oldukları gözlemlenmiştir. Aylık, yıllık ve iki yıllık periyotları kapsayan çalışmanın sonucunda kısa dönemli analizlerin rüzgâr türbinlerinde etkinlik kıyaslamalarında daha ayrıntılı bilgi sundukları gözlemlenmiştir. Önerilen SSA yaklaşımı sayesinde herhangi bir dönemde girdi parametreleri doğrultusunda hangi türbinin etkin çalıștığı, hangi türbinin düşük etkinlikle çalıştığı, bununla beraber, etkinsizliğin sebebinin ne oranda istatiksel sapmadan ne oranda teknik etkinsizlikten kaynaklandığı kolaylıkla yorumlanabilmektedir. Aynı yorumlar kullanılan zaman periyotları için ve çiftliğin genel durumu için de çıkarılabilir. Çalışmanın sonuçları işletme ile paylaşılıış ve işletme yöneticileri analizlerin bakım planlamalarında faydalı olabileceklerini belirtmişlerdir. Farklı girdilerdeki farklı etkinlik skorları sayesinde düşük etkinlik gösteren türbinlerin kullanılan girdi verileriyle ilgili muhtemel arıza olasılıklarının incelenmesi çalışma sonucunda işletme yöneticilerine sunulmuştur. Analiz sonuçlarının türbin yerleşim planıyla ilişkili olup olmadığını yorumlamak amacıyla yapılan çalışma da etkinlik skorlarının yerleşim planıyla ilgili olmadığını göstermiştir. Analizler incelendiğinde farklı zaman dilimlerinde farklı türbinlerin etkin ve etkinsiz olarak çıktıkları görülebilir. Sonuç olarak, bu çalışma literatüre ilk defa SSA yönteminin ayrı ayrı türbin etkinliklerinin analizinde kullanılmasıyla katkı sağlamış olup bu sayede türbin etkinlik seviyelerinin çeşitli girdi parametreleriyle kıyaslanabilmesi sağlanmıştır. Ayrıca, literatürde bulunan rüzgâr türbini etkinlik ve performans analizi yöntemlerine ekonometride kullanılan çok farklı bir yaklaşım kazandırmıştır. Bu doğrultuda literatüre önemli bir katkı sağlanması umulmaktadır. Çalışmanın yazarları, bu uygulamanın rüzgâr türbinlerinin sağlıklı işleyip işlemediğinin kontrol ve izlenmesi açısından gelecek çalışmalara örnek teşkil etmesini beklemektedirler. İleriki çalışmalarda, rüzgar türbinlerinin arıza kayıtlarının da elde edilmesi ve arıza gösteren parametrelerin girdi olarak kullanıldığ1 etkinlik analizleri tasarlanabilir. Belirli periyotlarla uygulanması öngörülen bu tarz parametrik etkinlik ölçüm modellemelerin arıza tahmini ve tespiti konusunda uyarıcı bir gösterge olması düşünülmektedir.

\section{SIMMELER (SYMBOLS)}

i : : Rüzgâr türbini sayısı

t : Periodlar

$\mathrm{u} \quad$ : Rastlantısal sistematik sapma

$\mathrm{U}_{\mathrm{i}} \quad$ : i türbininin etkinsizliğini

$\mathrm{U}_{\mathrm{it}} \quad$ : i türbininin t periyodundaki etkinsizliği

v : Çift yönlü istatiksel hata

$V_{\text {it }} \quad:$ i türbininin $t$ periyodundaki çift yönlü istatiksel sapmas1

X : Girdi vektörü

$\mathrm{X}_{\mathrm{i}} \quad$ : i türbininin girdileri

$\mathrm{X}_{\mathrm{it}} \quad$ : i türbininin $\mathrm{t}$ periyodu için girdileri

y : Çıktı vektörü

$\mathrm{Y}_{\mathrm{i}}^{*} \quad$ : i türbininin güç üretimini

$\mathrm{y}_{\text {it }} \quad$ : i türbininin $\mathrm{t}$ periyodundakigüç üretimini 
Yunan Harfleri (Greek Letters)

$\beta \quad$ : Bilinmeyenlerden oluşan katsayı vektörü

$\gamma \quad$ : Gama

$\delta \quad$ : Standart Sapma

\section{TEŞEKKÜRLER (ACKNOWLEDGEMENT)}

$\mathrm{Bu}$ çalışma sürecinde yazarlardan Yunus EROĞLU, TÜBİTAK tarafından desteklenmiş (TUBITAK - BIDEB 2214 A) ve çalışmanın bir kısmını Duisburg - Essen Üniversitesi, Enerji ve Güç Sistemleri bölümünde tamamlamıştır. Yunus EROĞLU, katkılarından dolayı TÜBİTAK ve Duisburg - Essen Üniversitesi Enerji ve Güç Sistemleri Bölümü’ne teşekkür eder.

\section{KAYNAKLAR (REFERENCES)}

1. WWEA, The World Wind Energy Association (WWEA) Half Year Report 2014. http://www.wwindea.org/wwea-publishes-half-yearreport-2014/. Yayın tarihi Eylül 2014.Erişirm tarihi Mart 29, 2016.

2. Da Rosa AV., Fundamentals of renewable energy processes, Elsevier, Amsterdam, 2013.

3. Eroğlu Y., Seçkiner S.U., Performance analysis in wind farms by data envelopment analysis and Malmquist Index approaches. Pamukkale Univ. J. Eng. Sci., 23(1), 45-54, 2017.

4. GWEC, Global Wind Report - Annual Market Update 2015.

http://www.gwec.net/wp-content/uploads/vip/GWECGlobal-Wind-2015-Report_April-2016_22_04.pdf.

Yayın tarihi Nisan 19 2014.Erișirm tarihi Nisan 21, 2016.

5. Turkish Wind Energy Association, Turkish Wind Energy Statistics Report.

http://www.tureb.com.tr/files/bilgi_bankasi/turkiye_res _durumu/2016_turkiye_ruzgar_enerji_istatistik_raporu ocak 2016.pdf. Yayın tarihi Ocak 2016.Erişirm tarihi Äğustos 9, 2016.

6. Onar S.Ç., Kılavuz T N., Risk Analysis of Wind Energy Investments in Turkey. Hum. Ecol. Risk Assess. Int. J., 21 (5), 1230-1245, 2015.

7. Onar S.C., Oztaysi B., Otay İ., Kahraman C., Multiexpert wind energy technology selection using intervalvalued intuitionistic fuzzy sets. Energy, 90 (1), 274-285, 2015.

8. Yang W., Tavner P.J., Crabtree C.J., Feng Y., Qiu Y., Wind turbine condition monitoring, technical and commercial challenges. Wind Energy, 17, 673-693, 2014.

9. Eroğlu Y., Seçkiner S.U., Trend Topic Analysis for Wind Energy Researches, A Data Mining Approach Using Text Mining. J. Technol. Innov. Renew. Energy, 5, 44-58, 2016.

10. Denholm P., Kulcinski G L., Holloway T., Emissions and Energy Efficiency Assessment of Baseload Wind Energy Systems. Environ. Sci. Technol., 39, 19031911, 2005.
11. Mirecki A., Roboam $X$., and Richardeau F., Architecture Complexity and Energy Efficiency of Small Wind Turbines. IEEE Trans. Ind. Electron., 54 (1), 660-670, 2007.

12. Zhang H., Tolbert L M., Efficiency Impact of Silicon Carbide Power Electronics for Modern Wind Turbine Full Scale Frequency Converter. IEEE Trans. Ind. Electron., 58, 21-28, 2011.

13. De Prada Gil M., Gomis-Bellmunt O., Sumper A., Bergas-Jané J., Power generation efficiency analysis of offshore wind farms connected to a SLPC (single large power converter) operated with variable frequencies considering wake effects. Energy, 37, 455-468, 2012.

14. Najar F.A., Harmain G.A., Blade Design and Performance Analysis of Wind Turbine. In, International Conference on Global Scenario in Environment and Energy. International Journal of Chem. Tech Research, 1054-1061, 2013.

15. Jiang H., Li Y., Cheng Z., Performances of ideal wind turbine. Renew. Energy, 83, 658-662, 2015.

16. Chehouri A., Younes R., Ilinca A., Perron J., Review of performance optimization techniques applied to wind turbines. Appl. Energy, 142, 361-388, 2015.

17. El-Baz A.R., Youssef K., Mohamed M.H., Innovative improvement of a drag wind turbine performance. Renew. Energy, 86, 89-98, 2016.

18. Astolfi D., Castellani F., Garinei A., Terzi L., Data mining techniques for performance analysis of onshore wind farms. Appl. Energy, 148, 220-233, 2015.

19. Mengi O.Ö., Altaş İ.H., A different fuzzy decision making MPPT method for a micro power wind turbine, Journal of the Faculty of Engineering and Architecture of Gazi University, 30 (2), 197-206, 2015.

20. Bayrak M., Eric N., Küçüker A., Detection of mechanical unbalanced faults in wind turbines by using electrical measurements, Journal of the Faculty of Engineering and Architecture of Gazi University, 31 (3), 687-694,2016.

21. Devrim Y., Bilir L., Performance investigation of a wind turbine-solar photovoltaic panels-fuel cell hybrid system installed at İncek region - Ankara, Turkey, Energy Convers. Manag., 126, 759-766, 2016.

22. Uluyol Ö., Parthasarathy G., Foslien W., Kim K., Power Curve Analytic for Wind Turbine Performance Monitoring and Prognostics. In, Annual Conference of the Prognostics and Health Management Society, 1-8., 2011.

23. Carrillo C., Obando Montaño A.F., Cidrás J., DíazDorado E., Review of power curve modelling for wind turbines. Renew. Sustain. Energy Rev., 21, 572-581, 2013.

24. Lydia M., Kumar S.S., Selvakumar A.I., Prem Kumar G.E., A comprehensive review on wind turbine power curve modeling techniques. Renew. Sustain. Energy Rev., 30, 452-460, 2014.

25. Milan P., Wächter M., Peinke J., Stochastic modeling and performance monitoring of wind farm power production. J. Renew. Sustain. Energy, 6, 33119, 2014. 
26. Herp J., Poulsen U.V., Greiner M., Wind farm power optimization including flow variability. Renew. Energy, 81, 173-181, 2015.

27. Kusiak A., Verma A., Monitoring Wind Farms With Performance Curves. IEEE Trans. Sustain. Energy, 4, 192-199, 2013.

28. Verma A., Performance monitoring of wind turbines, a data-mining approach, $\mathrm{PhD}$, University of Iowa, Iowa, 2012.

29. Wagner R., Antoniou I., Pedersen S.M., Courtney M.S., Jørgensen H.E., The influence of the wind speed profile on wind turbine performance measurements. Wind Energy, 12, 348-362, 2009.

30. Al-Hadhrami L.M., Performance evaluation of small wind turbines for off grid applications in Saudi Arabia. Energy Convers. Manag., 81, 19-29, 2014.

31. Barthelmie R.J., Jensen L.E., Evaluation of wind farm efficiency and wind turbine wakes at the Nysted offshore wind farm. Wind Energy, 13, 573-586, 2010.

32. Pieralli S., Ritter M., Odening M., Efficiency of wind power production and its determinants. Energy. 90, Part 1, 429-438, 2015.

33. Krokoszinski H.J., Efficiency and effectiveness of wind farms - keys to cost optimized operation and maintenance. Renew. Energy, 28, 2165-2178, 2003.

34. Bortolini M., Gamberi M., Graziani A., Manzini R., Pilati F., Performance and viability analysis of small wind turbines in the European Union. Renew. Energy, 62, 629-639, 2014.

35. Zhang Z., Performance optimization of wind turbines, Phd, University of Iowa, Iowa, 2012.

36. Eroğlu Y., Seçkiner S.U., Design of wind farm layout using ant colony algorithm. Renew. Energy, 44, 53-62, 2012.

37. Eroğlu Y., Seçkiner S.U., Wind farm layout optimization using particle filtering approach. Renew. Energy, 58, 95-107 ,2013.

38. Lo S.F., Wu C.Y., Evaluating the performance of wind farms in China, An empirical review. Int. J. Electr. Power Energy Syst., 69, 58-66, 2015.

39. Iglesias G., Castellanos P., Seijas A., Measurement of productive efficiency with frontier methods, A case study for wind farms. Energy Econ., 32, 1199-1208, 2010 .
40. Aigner D., Lovell C.A.K., Schmidt P., Formulation and estimation of stochastic frontier production function models. J. Econom., 6, 21-37, 1977.

41. Meeusen W., van Den Broeck J., Efficiency Estimation from Cobb-Douglas Production Functions with Composed Error. Int. Econ. Rev., 18, 435-444, 1977.

42. Zhou P., Ang B.W., Zhou D.Q., Measuring economywide energy efficiency performance, A parametric frontier approach. Appl. Energy, 90, 196-200, 2012.

43. Hu J.L., Honma S., A Comparative Study of Energy Efficiency of OECD Countries, An Application of the Stochastic Frontier Analysis. Energy Procedia, 61, 2280-2283, 2014.

44. Yu F.W., Chan K.T., Yang J., Sit R.K.Y., Comparative study on the energy performance of chiller system in an institutional building with stochastic frontier analysis. Energy Build., 89, 206-212, 2015.

45. Lin B., Long H., A stochastic frontier analysis of energy efficiency of China's chemical industry. J. Clean. Prod., 87, 235-244, 2015.

46. Battese G.E., Coelli T.J., A model for technical inefficiency effects in a stochastic frontier production function for panel data. Empir. Econ., 20, 325-332, 1995.

47. Battese G.E., Corra G.S., Estimation of a Production Frontier Model, With Application to the Pastoral Zone of Eastern Australia. Aust. J. Agric. Econ., 21, 169-179, 1977.

48. Coelli T.J., A guide to FRONTIER version 4.1, a computer program for stochastic frontier production and cost function estimation. CEPA Work. Pap. 7, 1-96, 1996.

49. Cordeiro J.J., Sarkis J., Vazquez-Brust D., Frater L., Dijkshoorn J., An evaluation of technical efficiency and managerial correlates of solid waste management by Welsh SMEs using parametric and non-parametric techniques. J. Oper. Res. Soc., 63, 653-664, 2012.

50. Kodde D.A., Palm F., Wald Criteria for Jointly Testing Equality and Inequality Restrictions. Econometrica, 54 (5), 1243-48, 1986.

51. Jacobs R., Smith P.C., Street A., Measuring Efficiency in Health Care, Analytic Techniques and Health Policy, Cambridge University Press, 2006. 
